\title{
Sodium butyrate promotes lipopolysaccharide-induced innate immune responses by enhancing mitogen-activated protein kinase activation and histone acetylation in bovine mammary epithelial cells
}

\author{
Hongyu Dai, Guozhen Wei, Yan Wang, Nana Ma, Guangjun Chang, and Xiangzhen Shen* () \\ Ministry of Education Joint International Research Laboratory of Animal Health and Food Safety, College of Veterinary Medicine, \\ Nanjing Agricultural University, Nanjing, 210095, P. R. China
}

\begin{abstract}
The innate immune response plays a crucial role in recovery from infectious diseases by promoting the clearance of pathogens. Sodium butyrate $(\mathrm{NaB})$ is an energy source for cellular processes with the potential to regulate the innate immune response. The present study aimed to evaluate the effect of $\mathrm{NaB}$ on the innate immune response in a bovine mammary alveolar cell line (MAC-T) initiated by lipopolysaccharides (LPS). Thus, treatments were conducted as follows: treated with $1 \times$ PBS for $24 \mathrm{~h}$ (control), pretreated with 1 $\mathrm{m} M \mathrm{NaB}$ (optimized by cell viability assays and dosedependent experiment) for $18 \mathrm{~h}$ followed by treatment of $1 \times$ PBS for $6 \mathrm{~h}(\mathrm{NaB})$, pretreated with $1 \times \mathrm{PBS}$ for $18 \mathrm{~h}$ followed by stimulation with LPS $(1 \mu \mathrm{g} / \mathrm{mL})$ for $6 \mathrm{~h}$ (LPS), and pretreated with $1 \mathrm{mM} \mathrm{NaB}$ for 18 $\mathrm{h}$ followed by stimulation with LPS $(1 \mu \mathrm{g} / \mathrm{mL})$ for 6 h $(\mathrm{NaB}+\mathrm{LPS})$. Different inhibitors were also used to elucidate the underlying mechanism. Furthermore, cells were treated with $\mathrm{NaB}$ and heat-inactivated Escherichia coli to test the effect of $\mathrm{NaB}$ on transcription of genes related to the innate immune response triggered by the major causative pathogen of mastitis. Each treatment had 3 replicates and was repeated 3 times. Proinflammatory cytokines, chemokines, and $\beta$-defensins are crucial secretion factors in innate immunity, and transcription of these factors was increased by $\mathrm{NaB}$ during challenge with LPS or heat-inactivated E. coli in MAC-T cells. Acetylation of histone H3 protein, which promotes gene expression by affecting the structure of chromatin, was also upregulated by $\mathrm{NaB}$ in response to LPS stimulation. P38 mitogen-activated protein kinases (MAPK), JNK, and Erk 1 and 2 are key upstream regulators of the expression of proinflammatory cytokines, chemokines, and $\beta$-defensins, and their
\end{abstract}

Received January 14, 2020.

Accepted July 22, 2020.

*Corresponding author: xzshen@njau.edu.cn activity was enhanced by NaB during LPS stimulation. Furthermore, inhibitors were used to assess the role of MAPK signaling in the effects of $\mathrm{NaB}$. The results showed that inhibitors of p38 MAPK, Erk, and JNK attenuated the NaB-induced upregulation of TNF and $\beta$-defensin 5 (DEFB5) transcription, and that the inhibitor of Erk attenuated the NaB-induced upregulation of $I L 1 B$ transcription during LPS challenge. Enhanced transcription of $C X C L 8$ by $\mathrm{NaB}$ was blocked by the inhibitor of Erk and p38 MAPK during LPS stimulation. Overall, NaB boosted the LPS-induced innate immune response by promoting the expression of proinflammatory cytokines, chemokines, and $\beta$-defensins, which was associated with enhanced MAPK signaling activation and histone $\mathrm{H} 3$ acetylation.

Key words: mastitis, histone acetylation, innate immunity, mammary epithelial cells

\section{INTRODUCTION}

Mastitis is one of the most prevalent diseases in the dairy industry, causing severe losses in milk yield and quality. Environmental pathogens, such as Klebsiella and Escherichia coli, are the major causative pathogens that induce clinical mastitis (Thompson-Crispi et al., 2014). Lipopolysaccharides are the primary components of outer membrane of gram-negative bacteria, which are recognized as strong stimuli provoking the innate or natural immune response (Alexander and Rietschel, 2001).

The innate immune response, a nonspecific immune response, plays a crucial role in the early stage of infection (Sordillo and Streicher, 2002; Rainard and Riollet, 2006). Upon recognition of LPS by toll-like receptor 4 (TLR4), activation of the nuclear factor $\kappa \mathrm{B}(\mathrm{NF}-\kappa \mathrm{B})$ and mitogen-activated protein kinase (MAPK) pathways occurs. Activation of these regulators subsequently regulates the expression of proinflammatory cytokines, chemokines, and $\beta$-defensins, which are crucial secretion factors in the innate immune response (Yang et al., 2006; Lu et al., 2008; Li et al., 2016). 
Proinflammatory cytokines (e.g., IL6, IL1B, and TNF) and chemokines [e.g., C-X-C motif chemokine ligand 2 (CXCL2) and C-X-C motif chemokine ligand 8 (CXCL8)] are small active proteins. These proteins modulate the innate immune response by affecting the differentiation and transmigration of immune cells once they are released by the stimulated cells (Kunkel et al., 1991; Scheller et al., 2011; Rouault et al., 2013; Borthwick, 2016). $\beta$-Defensins are active antimicrobial peptides deployed by the innate immune defense system against gram-positive and gram-negative bacteria, viruses, and fungi (Zasloff, 2002; Roosen et al., 2004). Lingual antimicrobial peptide (LAP), tracheal antimicrobial peptide (TAP), and $\beta$-defensin 5 (DEFB5) are the major components of $\beta$-defensin and play an important role in defending against infection of the bovine mammary gland (Goldammer et al., 2004; Swanson et al., 2004). These secreted factors are released at the beginning of an infection and have nonspecific antimicrobial properties. Adequate expression of these factors is essential for the clearance of invading pathogens and recovery from the infection.

Butyrate is not only an energy source of cells; it also exerts modulatory effects on the immune response (Meijer et al., 2010). Sodium butyrate is often selected in research as an alternative compound to butyrate acid because it is solid and more stable. Some studies have suggested that sodium butyrate $(\mathrm{NaB})$ inhibits inflammation in the lung of mouse and in human lamina propria cells by attenuating the activation of NF- $\kappa$ B initiated by LPS (Segain et al., 2000; Liu et al., 2019). Additionally, as a histone deacetylase inhibitor, $\mathrm{NaB}$ has been demonstrated to enhance the expression of TNF- $\alpha$ in MonoMac 6 cells in response to phorbol 12-myristate 13-acetate (PMA) stimulation (Lee et al., 2003). A positive effect of butyrate has also been reported in bovine mammary epithelial cells during Staphylococcus aureus infection by reducing the internalization of Staph. aureus (Alva-Murillo et al., 2015). The results of a previous study suggested that $\mathrm{NaB}$ upregulates the cathelicidin and $\beta$-defensin 9 in human lung epithelial cells and in chickens (Kida et al., 2006; Sunkara et al., 2014).

Previous studies have mainly focused on the effects of $\mathrm{NaB}$ on immune cells or on its antitumor properties, and Sun et al. demonstrated that $\mathrm{NaB}$ modulated the inflammatory responses of mammary epithelial cells triggered by LPS by affecting NF- $\kappa \mathrm{B}$ signaling and histone H3 acetylation (Sun et al., 2020). Accordingly, in the present study, we aimed to further explore the molecular mechanisms involved in the regulatory effect of $\mathrm{NaB}$ on the LPS-induced innate immune response in MAC-T cells, via analyzing the expression of pro- inflammatory cytokines, chemokines, and $\beta$-defensin, and activation of NF- $\kappa \mathrm{B}$ and MAPK signaling. We hypothesized that $\mathrm{NaB}$ might also exert positive effects on the innate immune response during infection of the mammary gland. To this end, a bovine mammary alveolar cell line was selected and stimulated with LPS and $\mathrm{NaB}$ to elucidate the modulatory effect of $\mathrm{NaB}$ on the innate immune response during infection of the mammary gland in vitro.

\section{MATERIALS AND METHODS}

\section{Reagents}

All reagents used in cell culture including Roswell Park Memorial Institute (RPMI) medium 1640 basic $(1 \times)$, heat-inactivated fetal bovine serum, penicillin, and streptomycin were purchased from Gibco (Thermo Fisher Scientific, Waltham, MA). NF-kB p65, phospho-

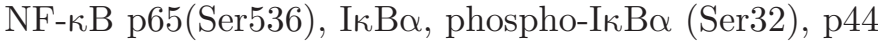
and p42 MAPK (Erk1 and 2), PhosphoPlus p44 and p42 MAPK (Erk 1 and 2, phosphorylated at Thr202 and Tyr204, respectively), p38 MAPK XP, phosphop38 MAPK (Thr180 and Tyr182) XP, SAPK and JNK, phospho-SAPK and JNK (Thr183 and Tyr185), ACTB, and GAPDH antibody were obtained from Cell Signaling Technology (Danvers, MA). HRP-linked goat anti-rabbit IgG, HRP-linked goat anti-mouse IgG, and FITC-labeled goat anti-rabbit IgG were purchased form Beyotime Biotechnology (Nanjing, Jiangsu, China). Histone $\mathrm{H} 3$ and acetyl-histone H3 (Lys 9, 14, 18, 23, and 27) antibody were purchased from Affinity Biosciences (Cincinnati, OH). Trichostatin A (TSA), BAY 11-7085, SB203580, AG126, and JNK-IN-8 were purchased from MedChem Express (Monmouth Junction, NJ). Sodium butyrate and LPS from E. coli 055:B5 were purchased from Sigma-Aldrich (Burlington, MA). Escherichia coli used for stimulation was isolated from a clinical case of bovine mastitis; the isolate belongs to the serotype O15 E. coli strain and was heat-inactivated before use. Other reagents used in immunofluorescence and Western blotting were purchased from Solarbio Life Sciences (Beijing, China).

\section{Cell Culture and Treatments}

Frozen immortalized bovine mammary epithelial cells (MAC-T, kindly provided by the laboratory of J. J. Loor, Department of Animal Sciences, Division of Nutritional Sciences, University of Illinois, Urbana) were recovered and cultured in RPMI medium 1640 basic $(1 \times)$ supplemented with $10 \%$ heat-inactivated fetal bovine serum, $100 \mathrm{U} / \mathrm{mL}$ penicillin, and $100 \mu \mathrm{g} /$ 
$\mathrm{mL}$ streptomycin at $37^{\circ} \mathrm{C}$ in a humidified atmosphere with $5 \% \mathrm{CO}_{2}$. Cells between 8 and 15 passages were used for the study.

For the cell viability assay, MAC-T cells were pretreated with either $1 \times \mathrm{PBS}$ or $\mathrm{NaB}(1,2,4,6$, or 8 $\mathrm{m} M)$ for $18 \mathrm{~h}$ and then treated with or without LPS $(1 \mu \mathrm{g} / \mathrm{mL})$ for another $6 \mathrm{~h}$. Cells were preincubated with $1 \times$ PBS or $\mathrm{NaB}(0.25,0.5,1,2$, or $4 \mathrm{mM})$ for 18 $\mathrm{h}$ and then treated with or without LPS $(1 \mu \mathrm{g} / \mathrm{mL})$ for another $6 \mathrm{~h}$ in the incubator, and mRNA abundances of $T N F, I L 1 B$, and DEFB5 were evaluated to optimize the dose of $\mathrm{NaB}$ used, for later analyses of the present study ( $1 \mathrm{~m} M$ was the optimized dose, as described in the Results and Discussion section). Thereafter, MACT cells were pretreated with $1 \mathrm{~m} M \mathrm{NaB}$ or $1 \times$ PBS for $18 \mathrm{~h}$, followed by another 6 -h LPS challenge. Then cell supernatant was collected for ELISA analysis, and cells were collected for genes and protein analysis.

Different inhibitors [histone deacetylase TSA (cells preincubated with $100 \mu M$ TSA for 30 min before LPS stimulation), NF- $\kappa$ B (BAY 11-7085; cells preincubated with 2 or $10 \mu M$ BAY 11-7085 for $1 \mathrm{~h}$ before LPS challenge), p38MAPK (SB203580; cells preincubated with $10 \mu M$ SB203580 for $2 \mathrm{~h}$ before LPS stimulation), Erk (AG126; $30 \mu M$ AG126 used simultaneously with LPS stimulation), and JNK (JNK-IN-8, cells preincubated with $3 \mu M$ JNK-IN-8 JNi for 30 min before LPS stimulation)] were also used to analyze the mechanism of the regulatory effect of NaB. Dimethyl sulfoxide (DMSO) was used to dissolve the inhibitors, and final concentration of DMSO in the cell culture medium was $0.2 \%$. To test the effects of $\mathrm{NaB}$ on the innate immune response induced by major causative bacterial, MAC-T cells were pretreated with $1 \mathrm{~m} M \mathrm{NaB}$ or $1 \times$ PBS for 18 h, followed by treatment with heat-inactivated $E$. coli $\left(1 \times 10^{5} \mathrm{cfu} / \mathrm{mL}\right.$; multiplicity of infection $\left.=0.1\right)$ for 6 h. Then cells were collected for real-time quantitative PCR (RT-qPCR) analysis.

\section{Cell Viability Assay}

The cell viability assay was conducted according to the instructions of the cell counting kit (CCK-8, ZetaLife, San Francisco, CA). Briefly, MAC-T cells were seeded into a 96 -well plate with $5 \times 10^{3}$ cells in each well. Pre-incubation was conducted by adding $100 \mu \mathrm{L}$ of medium containing different concentration of $\mathrm{NaB}(1$, $2,4,6$, or $8 \mathrm{~m} M)$ or $1 \times \mathrm{PBS}$, with 4 replicates for each concentration, and cells were incubated for $18 \mathrm{~h}$. Cells were subsequently treated with or without $1 \mu \mathrm{g} / \mathrm{mL}$ of LPS and incubated for another $6 \mathrm{~h}$. Subsequently, $10 \mu \mathrm{L}$ of CCK-8 solution was added to each well, fol- lowed by incubation for $4 \mathrm{~h}$. Absorbance was measured at $450 \mathrm{~nm}$ using a microplate reader (Thermo Fisher Scientific). Viability was calculated by dividing the absorbance of treatments by the absorbance of control.

\section{ELISA}

We seeded MAC-T cells in 12 -well plates with $1 \times 10^{5}$ cells in each well and pretreated them with $1 \mathrm{~m} M \mathrm{NaB}$ or $1 \times$ PBS for $18 \mathrm{~h}$. Cells were then challenged with or without $1 \mu \mathrm{g} / \mathrm{mL}$ of LPS for $6 \mathrm{~h}$. Cell supernatant was collected, and the concentrations of DEFB5 and TNF- $\alpha$ in supernatants were measured using a bovine DEFB5 ELISA kit and a bovine TNF- $\alpha$ ELISA kit (both from Jin Yibai Biotechnology, Nanjing, Jiangsu, China), following the kits' instructions. Sensitivities of the kits are $6 \mathrm{ng} / \mathrm{L}$ and $20 \mathrm{ng} / \mathrm{L}$, respectively. Intraassay percent coefficient of variation $(\mathrm{CV}) \leq 9$, and interassay percent $\mathrm{CV} \leq 11$.

\section{RNA Isolation, cDNA Synthesis, and RT-qPCR}

Cells were seeded in 12 -well plates with $1 \times 10^{5}$ cells in each well, and were treated as described in the Cell Culture and Treatment section. Cells were then washed twice with $1 \times$ PBS at the end of treatment, and total RNA was isolated with an RNAiso Plus Kit (Takara Co., Dalian, Liaoning, China) according to the manufacturer's instructions. Concentration of RNA was measured using a Nano Drop ND-2000 spectrophotometer (Thermo Fisher Scientific). Only RNA with ratios of A260 to A280 between 1.8 and 2.0 were used for later experiments. The integrity of the RNA was evaluated via $1 \%$ agarose gel electrophoresis.

A total of $500 \mathrm{ng}$ of RNA was reverse-transcribed to complementary DNA (cDNA) via HiScript II Q RT SuperMix for qPCR kit (Vazyme, Nanjing, Jiangsu, China) according to the manufacturer's instructions. The cDNA was diluted 4-fold, and genes associated with proinflammatory cytokines (IL6,IL1B, and TNF), chemokines (CXCL2 and CXCL8), and $\beta$-defensins (TAP, $L A P$, and $D E F B 5)$ were assessed via RT-qPCR using a ChamQ SYBR qPCR Master Mix Kit (Vazyme) in accordance with the manufacturer's instructions. Realtime qPCR reactions were performed on an ABI 7300 system (Thermo Fisher Scientific) with the following conditions: denaturation at $95^{\circ} \mathrm{C}$ for $30 \mathrm{~s}$, followed by 40 cycles of $95^{\circ} \mathrm{C}$ for $10 \mathrm{~s}$ and $60^{\circ} \mathrm{C}$ for $30 \mathrm{~s}$. The threshold cycle data were analyzed and normalized to GAPDH, which has been tested as a reference gene in our previous study (Ma et al., 2019). Data from RT-qPCR was analyzed using the $2^{-\Delta \Delta \mathrm{CT}}$ method, as described in a 
previous study (Livak and Schmittgen, 2001). Information on primers used in the present study is listed in Table1.

\section{Immunofluorescence}

Immunofluorescence was performed as described by Ma et al. (2019) with some modifications. Briefly, $5 \times$ $10^{3}$ cells were seeded on the cover slips placed in the bottom of a 12-well plate. Cells were pretreated with $1 \mathrm{~m} M \mathrm{NaB}$ or $1 \times$ PBS for $18 \mathrm{~h}$ and were subsequently stimulated with or without $1 \mu \mathrm{g} / \mathrm{mL}$ of LPS for $6 \mathrm{~h}$. Cells were washed with $1 \times$ PBS 3 times and then fixed with $4 \%$ paraformaldehyde $(500 \mu \mathrm{L} /$ well $)$ for $15 \mathrm{~min}$ at room temperature. Paraformaldehyde was removed, and cells were washed 3 times with $500 \mu \mathrm{L}$ of $1 \times$ PBS. Then $500 \mu \mathrm{L}$ of $0.3 \%$ Triton $\mathrm{X}-100$ in $1 \times$ PBS was added to each well, and cells were incubated at room temperature for 15 min. Triton X-100 was removed, and cells were washed 3 times with $1 \times$ PBS. Then 500 $\mu \mathrm{L}$ of $5 \%$ BSA in $1 \times$ PBS with $0.3 \%$ Triton X-100 was added to each well, and cells were incubated for $1 \mathrm{~h}$ at room temperature. Anti-NF- $\mathrm{B}$ p65 antibody, diluted in antibody buffer (1\% BSA and $0.3 \%$ Triton X-100 in $1 \times$ PBS, diluted 1:100), was added to the cells, and they were incubated at $4^{\circ} \mathrm{C}$ overnight. Cells were then washed with $1 \times$ PBS 3 times and incubated in darkness with FITC-labeled goat anti-rabbit antibody diluted in antibody buffer (diluted $1: 500$ ) at $37^{\circ} \mathrm{C}$ for $1 \mathrm{~h}$. Cells were then stained with $4^{\prime}, 6$-diamidino2-phenylindole (DAPI) for $5 \mathrm{~min}$ at room temperature after washing 3 times with $1 \times$ PBS. Cover slips were washed 3 times with $1 \times$ PBS and mounted on slides with antifade mounting medium. The expression of

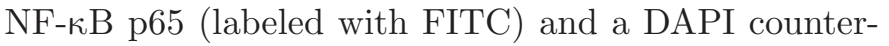
stain was visualized using an LSM 710 confocal laser microscope system (Zeiss, Oberkochen, Germany) with 488-nm and 405-nm lasers.

\section{Western Blotting}

Cells were seeded in 6 -well plates with $5 \times 10^{5}$ cells in each well and then were pretreated with or without 1 $\mathrm{m} M \mathrm{NaB}$ for $18 \mathrm{~h}$ and were challenged with or without $1 \mu \mathrm{g} / \mathrm{mL}$ of LPS for $6 \mathrm{~h}$. Cells were washed 3 times with $1 \times$ PBS and lysed with radioimmunoprecipitation assay (RIPA) lysis buffer. Concentration of protein in cell lysate was measured with a BCA Protein Assay Kit (Thermo Fisher Scientific). Then $30 \mu \mathrm{g}$ of total protein were separated on a $10 \%$ SDS-PAGE gel and

Table 1. Information on primers used in the present study

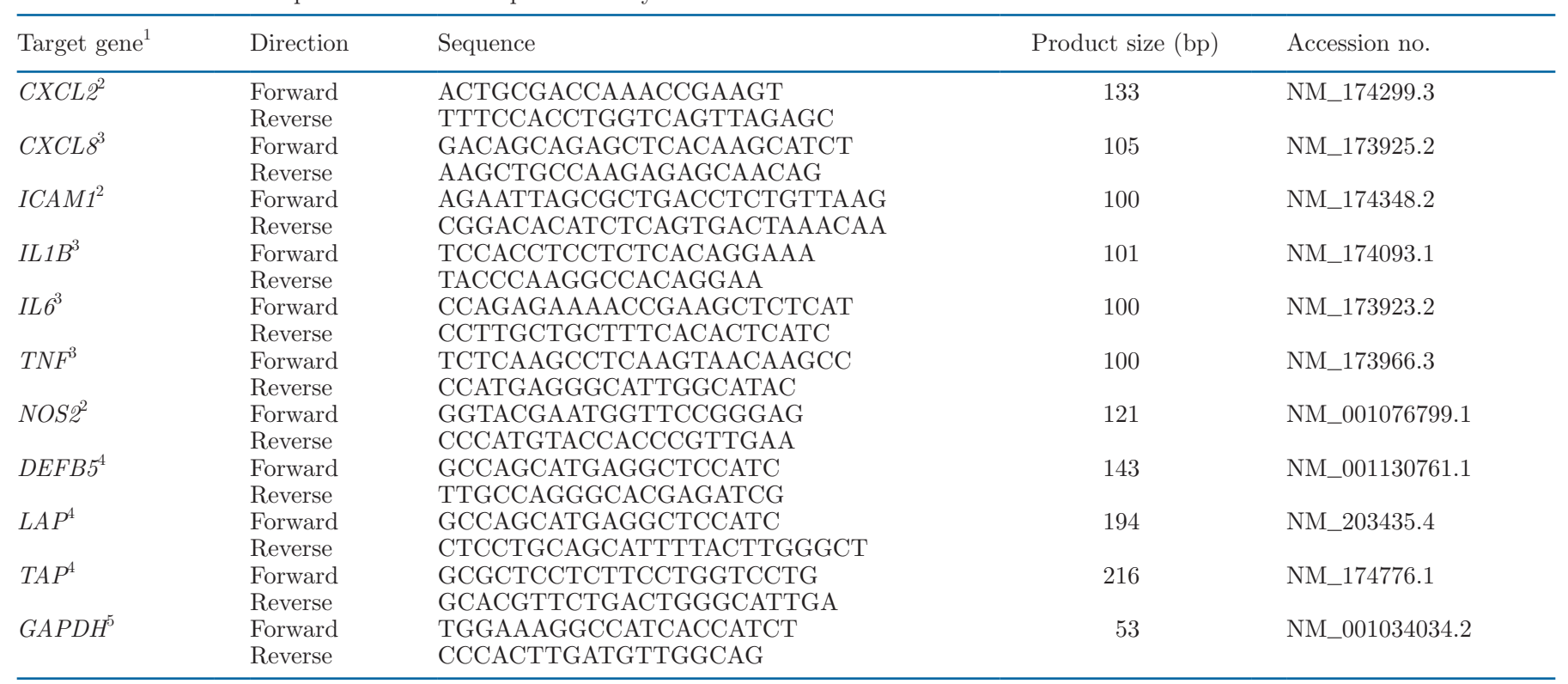

${ }^{1} C X C L 2=$ chemokine $(\mathrm{C}-\mathrm{X}-\mathrm{C}$ motif) ligand 2; CXCL8 = chemokine (C-X-C motif) ligand 8; ICAM1 = intercellular cell adhesion molecule-1; $T N F=$ tumor necrosis factor; NOS2 = nitric oxide synthase, inducible; DEFB $=\beta$-defensin $5 ; L A P=$ lingual antimicrobial peptide; TAP $=$ tracheal antimicrobial peptide.

${ }^{2}$ Primers were designed with Primer 6.0 software (Premier Biosoft International, Palo Alto, CA). The specificity and efficiency of the primers were tested before use.

${ }^{3}$ Primers were reported in previous study (Moyes et al., 2014).

${ }^{4}$ Primers were used by Alva-Murillo et al. (2015).

${ }^{5}$ Primer was adapted from previous study (Ma et al., 2019). 
transferred onto a polyvinylidene difluoride (PVDF) membrane. The membrane was blocked with $5 \%$ skim milk or BSA in $1 \times$ Tris-buffered saline containing $0.1 \%$ Tween 20 (TBST) at room temperature for $2 \mathrm{~h}$. Membranes were subsequently incubated with anti NF- $\mathrm{B}$

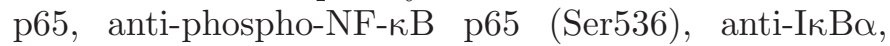

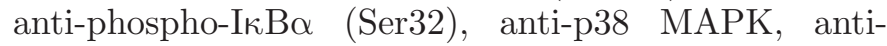
phospho-p38MAPK (Thr180 and Tyr182), anti-JNK, anti-phospho-JNK (Thr183 and Tyr185), anti-Erk 1 and 2, anti-phospho-Erk 1 and 2 (Thr202 and Tyr204), anti-histone H3, and anti-acetyl-histone H3 (Lys 9, 14, 18, 23, and 27) antibodies (all antibodies diluted with TBST $1: 1,000$ ) at $4^{\circ} \mathrm{C}$ overnight. Membranes were then washed with TBST 6 times (5 min/wash) and then were subjected to incubation with HRP-labeled goat anti-rabbit (1:5,000 dilution) or goat anti-mouse antibody (1:5,000 dilution) for $2 \mathrm{~h}$ at room temperature. After the washing with TBST 6 times (5 min/wash), the membranes were visualized with Clarity Western ECL substrate (Bio-Rad, Berkeley, CA) and scanned using the ChemiDoc MP system (Bio-Rad). Intensities of the bands were analyzed with Image Lab software (version 3.0, Bio-Rad), and GAPDH or ACTB were used as internal reference proteins for normalization; results were presented as relative protein abundance.

\section{Statistical Analysis}

Data were analyzed via one-way ANOVA with Tukey's post hoc test, using SPSS 20.0 for Windows (IBM Corp., Armonk, NY), and normality distribution of variables were assessed using the Shapiro-Wilk test. Results were presented as mean \pm standard error of the mean. All experiments were repeated 3 times, with triplicates in each treatment. Significance was set at $P$ $\leq 0.05$.

\section{RESULTS AND DISCUSSION}

Mastitis is an infectious disease that seriously affects the dairy industry. Mastitis causes a dramatic loss of milk yield and quality and leads to massive antibiotic use, premature culling, and other adverse consequences. The innate immune system is the first protective barrier against pathogens. This system involves both cellular defense and soluble products (such as cytokines, chemokines, and antimicrobial peptides; Rainard and Riollet, 2006). Thus, enhancement of the innate immune response is of great benefit for defending against pathogens and for recovery from infection.

Butyrate is a short-chain fatty acid that is a natural product in the rumen and cecum of ruminants and in the colon of rodents. Studies on immune cells, Crohn's disease, and mouse acute lung injury have reported a modulatory effect of $\mathrm{NaB}$ on immunity (Segain et al., 2000; Lee et al., 2003; Meijer et al., 2010; Liu et al., 2019). Therefore, we speculated that NaB might also have a positive effect on the innate immune response triggered by mammary infection. Although a recent study reported that $\mathrm{NaB}$ reduced bovine mammary epithelial cell inflammatory responses induced by LPS (Sun et al., 2020), we found a positive effect of $\mathrm{NaB}$ on the expression of genes related to the innate immune response during LPS stimulation in bovine mammary epithelial cells (MAC-T cells).

\section{Effect of $\mathrm{NaB}$ on Expression of TNF, IL1B, and DEFB5 in MAC-T Cells During LPS Stimulation}

Cell viability assays were performed first to assess the toxicity of NaB on MAC-T cells during LPS stimulation and to explore a safe range of concentrations for later experiments. The maximum concentration of $\mathrm{NaB}$ used in the cell viability assay was quite larger (8 $\mathrm{m} M)$. Results showed that the viability of MAC-T cells was dramatically suppressed when the concentration of $\mathrm{NaB}$ reached $2 \mathrm{~m} M$ or more $(P<0.05$; Figure $1 \mathrm{~A})$ during LPS stimulation.

Based on the results of cell viability assays, different concentrations of $\mathrm{NaB}$ (from 0.25 to $4 \mathrm{mM}$ ) were selected to evaluate the effect of $\mathrm{NaB}$ on the expression of genes related to the innate immune response during LPS stimulation. We found that abundances of $T N F, I L 1 B$, and DEFB 5 transcripts were significantly upregulated by $\mathrm{NaB}$ during LPS stimulation compared with the control and with cells stimulated with LPS only $(P<0.05$, Figure $1 \mathrm{~B}-\mathrm{D})$. Additionally, the effect of $\mathrm{NaB}$ on the transcription of TNF, IL1B, and DEFB5 during LPS stimulation was dose-dependent, and the maximum upregulatory effect of $\mathrm{NaB}$ was observed at $1 \mathrm{~m} M$ (Figure 1B-D). Therefore, $1 \mathrm{~m} M$ of $\mathrm{NaB}$ was selected as the optimal dose that did not affect cell viability and had maximum effect on the transcription of genes related to the innate immune response.

The increased expression of proinflammatory cytokines (TNF, IL1B, and $I L 6)$, chemokines (CXCL2 and $C X C L 8)$, and defensins (DEFB5 and TAP) triggered by $\mathrm{NaB}$ during LPS stimulation in the present study suggested a promoting effect of $\mathrm{NaB}$ on innate immunity. These findings are consistent with previous reports in which $\mathrm{NaB}$ promoted the expression of TNF in monocytes and U937.1 macrophages during PMA stimulation (Lee et al., 2003) and upregulated transcription of cathelicidin, an antimicrobial peptide, in a human lung epithelial cell line (Kida et al., 2006). However, NaB at- 
tenuated the mRNA abundance of TNF, IL1B, and IL6 in IFN-Y-stimulated RAW 264.7 murine macrophage (Park et al., 2007), and Sun et al. found that $\mathrm{NaB}$ reduced mRNA abundance of $T N F, I L 1 B$, and $I L 6$ in bovine mammary epithelial cells initiated by LPS (Sun et al., 2020). These observations are contradictory to the results generated in the present study, which suggests that the effect of $\mathrm{NaB}$ on the mRNA abundance of genes related to the innate immune response requires further exploration.

Upregulation of proinflammatory cytokines, chemokines, and $\beta$-defensins will recruit immune cells, facilitate elimination of pathogens and stimuli, and promote recovery from infection. Furthermore, these findings were confirmed by the detection of greater concentrations of TNF and DEFB5 in cell supernatant $(P<$ 0.05 , Figure 2A, B) and a greater abundance of ICAM1
$(P<0.05$, Figure $2 \mathrm{C})$ in response to $\mathrm{NaB}$ during LPS stimulation in the present study. Intercellular cell adhesion molecule-1 (ICAM1) is a crucial intercellular cell adhesion molecule that facilitates the adhesion and transmigration of neutrophils to an infected site (Yang et al., 2005).

The results of the current study also suggested that $\mathrm{NaB}$ enhanced the mRNA abundance of proinflammatory cytokines (TNF, IL1B, and IL6), chemokines (CXCL2 and $C X C L 8)$, and $\beta$-defensins (DEFB5, TAP, and $L A P$ ) induced by LPS in MAC-T cells, both as a pretreatment $(P<0.05$, Figure $3 \mathrm{~A}-\mathrm{C})$ and with simultaneous application $(P<0.05$, Figure $3 \mathrm{D}-\mathrm{F})$. Preincubation with $\mathrm{NaB}$ dramatically enhanced the mRNA abundance of genes related to the innate immune response induced by LPS, suggesting that $\mathrm{NaB}$ has a preventive effect on mammary epithelial cells against
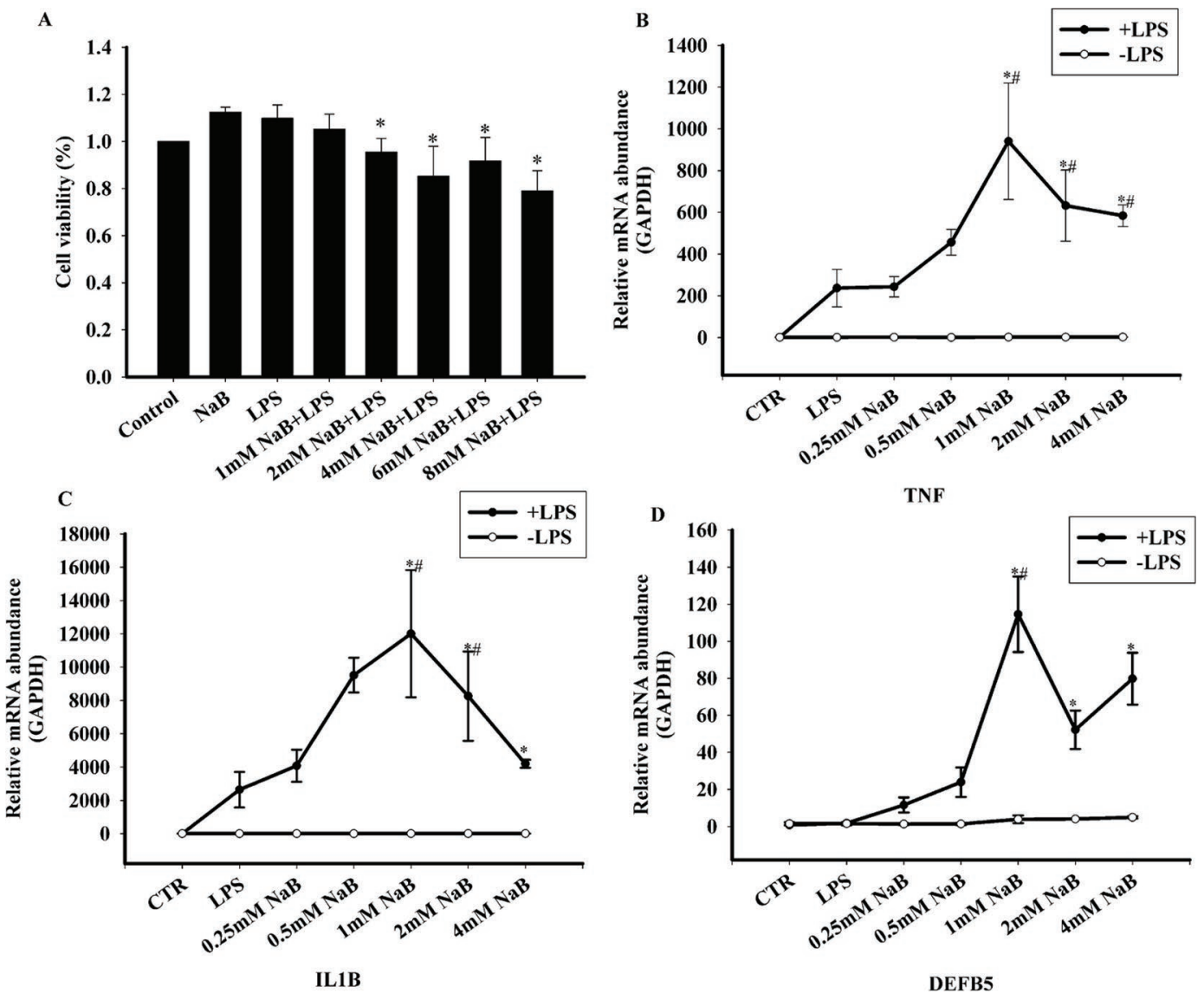

Figure 1. Effects of sodium butyrate (NaB) on mRNA abundance of genes related to innate immune response in MAC-T cells during LPS stimulation. (A) Viability of MAC-T in response to different concentration of NaB during LPS stimulation. Cells were pretreated with different concentration of $\mathrm{NaB}(1,2,4,6$, or $8 \mathrm{mM}$ ) or $1 \times \mathrm{PBS}$ (control) for $18 \mathrm{~h}$, followed by LPS stimulation for 6 h, after which cell viability assay was performed. (B-D) Relative mRNA abundance of $T N F, I L 1 B$, and DEFB5 in response to different concentration of NaB $(0.25,0.5,1,2$, or $4 \mathrm{mM}$ ) during LPS stimulation. -LPS = cells were treated with $1 \times$ PBS for $6 \mathrm{~h} ;+\mathrm{LPS}=$ cells were challenged with $1 \mu \mathrm{g} / \mathrm{mL}$ LPS for $6 \mathrm{~h}$. All data presented as mean \pm SEM *indicates significant difference compared with control (CTR). \#indicates significant difference compared with LPS stimulation only. 
A

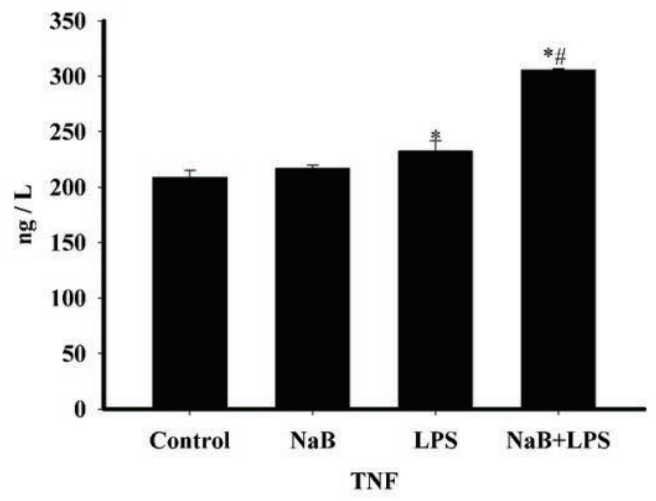

B

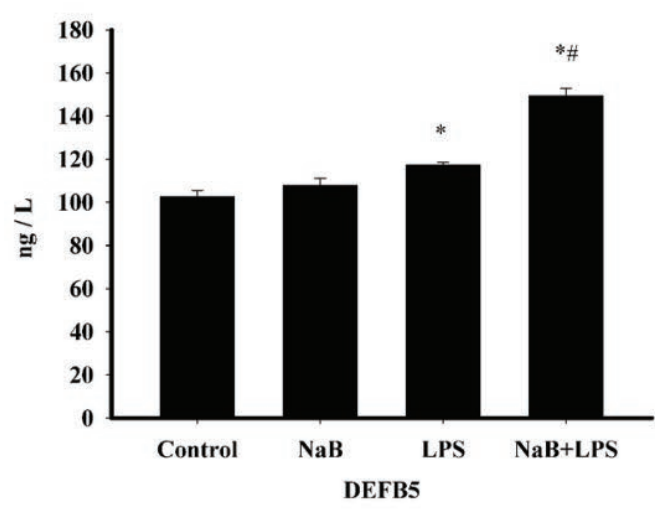

C

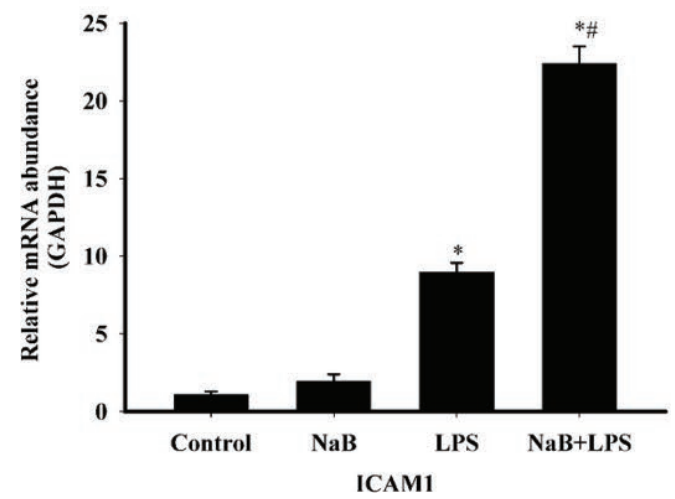

Figure 2. Effects of sodium butyrate $(\mathrm{NaB})$ on the release of TNF and DEFB5, and mRNA abundance of ICAM1 in MAC-T cells during LPS stimulation. Cells were pre-incubated with $1 \mathrm{~m} M \mathrm{NaB}$ for $18 \mathrm{~h}$ followed by stimulation with $1 \mu \mathrm{g} / \mathrm{mL}$ of LPS for another $6 \mathrm{~h}$. (A, B) Concentrations of TNF and DEFB5 in supernatant were determined via ELISA assay. (C) Relative mRNA abundance of ICAM1. Control $=$ cells were treated with $1 \times \mathrm{PBS} ; \mathrm{NaB}=$ cells were pretreated with $1 \mathrm{mM}$ of $\mathrm{NaB}$ for $18 \mathrm{~h}$ and then treated with $1 \times \mathrm{PBS}$ for another $6 \mathrm{~h}$ LPS $=$ cells were pretreated with $1 \times$ PBS for $18 \mathrm{~h}$ and then treated with $1 \mu \mathrm{g} / \mathrm{mL}$ of LPS for $6 \mathrm{~h} ; \mathrm{NaB}+\mathrm{LPS}=$ cells were pretreated with $1 \mathrm{mM}$ of $\mathrm{NaB}$ for $18 \mathrm{~h}$ followed by stimulation with $1 \mu \mathrm{g} / \mathrm{mL}$ of LPS for another $6 \mathrm{~h} ; \mathrm{n}=3$. All data presented as mean \pm SEM. *indicates significant difference compared with control. \#indicates significant difference compared with LPS. the stimulation of pathogens. This means that $\mathrm{NaB}$ prepares the cells to respond more effectively to the stimulation or invading pathogens. We also found that $\mathrm{NaB}$ enhanced mRNA abundance of genes related to the innate immune response when used simultaneously with LPS stimulation, suggesting that $\mathrm{NaB}$ is helpful during the clearance of pathogens by enhancing the innate immune response.

\section{$\mathrm{NaB}$ Inhibits the Activity of NF-KB Signaling During LPS Stimulation}

Nuclear factor $\kappa \mathrm{B}$ is a crucial transcription factor that is involved in many biological processes, including the release of cytokines (Kulms and Schwarz, 2006). However, a higher level of $\mathrm{I} \kappa \mathrm{B} \alpha$ protein $(P<0.05$, Figure 4A, B) and lower level of phosphorylated I $\kappa \mathrm{B} \alpha$ protein $(P<0.05$, Figure $4 \mathrm{~A}, \mathrm{C})$ were observed in cultures with $\mathrm{NaB}+$ LPS than in the control and the group with LPS stimulation only.

A similar trend was observed for the protein abundance of phosphorylated NF- $\kappa \mathrm{B}$ p65 in response to $\mathrm{NaB}+$ LPS treatment $(P<0.05$, Figure $4 \mathrm{~A}, \mathrm{E})$, which indicated that the activity of $\mathrm{NF}-\kappa \mathrm{B}$ was suppressed by $\mathrm{NaB}$ during LPS challenge in the present study. A similar effect of $\mathrm{NaB}$ has also been reported in previous literature, in which $\mathrm{NaB}$ was found to inhibit the activity of NF- $\kappa \mathrm{B}$ in Crohn's disease and acute kidney injury (Segain et al., 2000; Machado et al., 2012; Liu et al., 2019), and a similar result was also reported in bovine mammary epithelial cell inflammatory responses induced by LPS (Sun et al., 2020).

Additionally, the translocation of NF- $\kappa$ B from the cytoplasm into the nucleus, which is induced by LPS, was also attenuated by $\mathrm{NaB}$ (Figure 5), which augmented the suppressive effect of $\mathrm{NaB}$ on NF- $\kappa \mathrm{B}$ activity during LPS stimulation. A previous study showed that inducible nitric oxide synthase (NOS2) downregulated the activity of NF- $\kappa$ B by S-nitrosylation via promoting the generation of nitric oxide during LPS-induced airway inflammation (Kelleher et al., 2011). In the present study, NOS2 was upregulated by $\mathrm{NaB}+$ LPS, compared with LPS only and with the control $(P<0.05$, Figure $4 \mathrm{~F}$ ). This upregulation of NOS2 also increased the inhibitory effect of $\mathrm{NaB}$ on the activation of NF- $\kappa \mathrm{B}$. Interestingly, a significant upregulation of $T N F, I L 1 B$, DEFB 5 , and CXCL8 by NaB during LPS stimulation was observed even after cells were treated with Bay 11-7085, which is a specific NF- $\kappa \mathrm{B}$ activation inhibitor $(P<0.05$, Figure 6$)$. Thus, these data suggest that mechanisms other than NF- $\kappa B$ signaling are involved in the upregulation of TNF, IL1B,CXCL8, and DEFB5 by $\mathrm{NaB}$ during LPS challenge. 
A

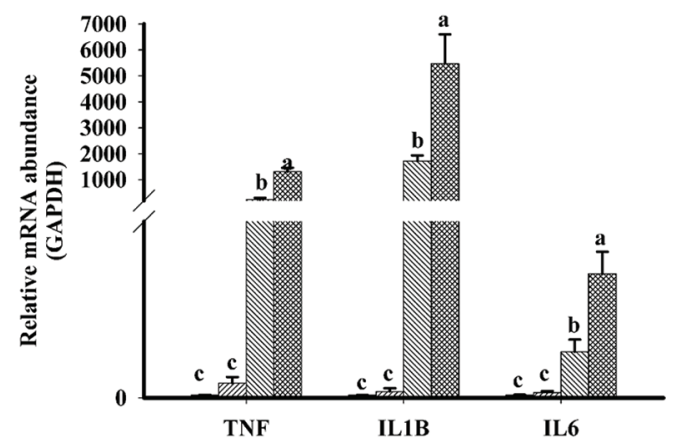

B

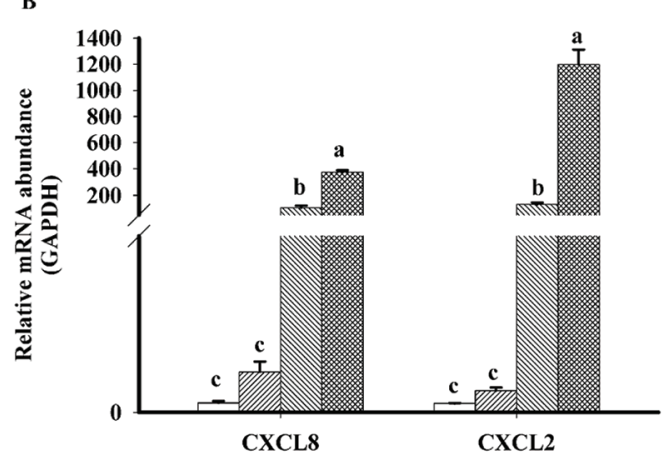

C

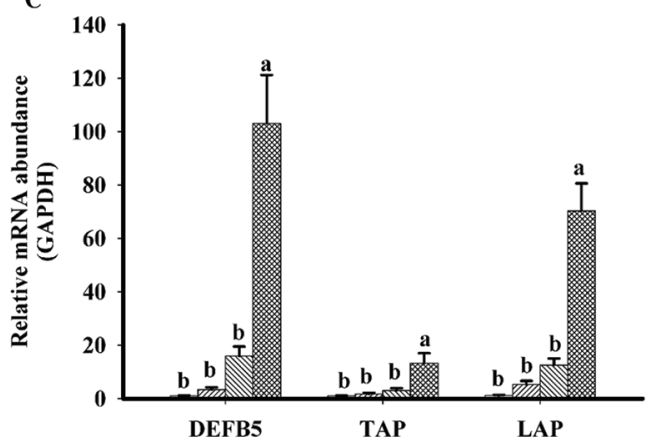

D

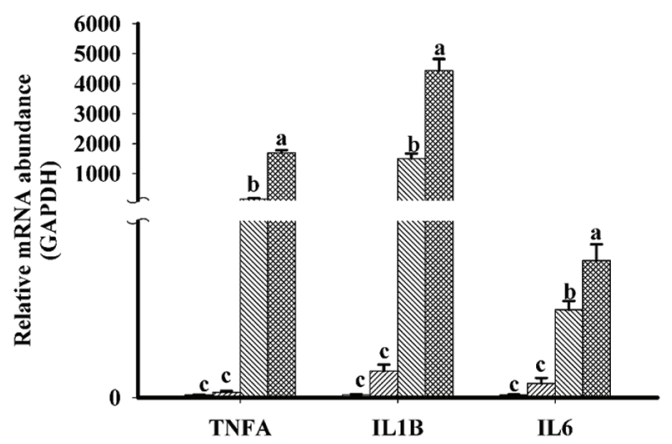

$\mathbf{E}$
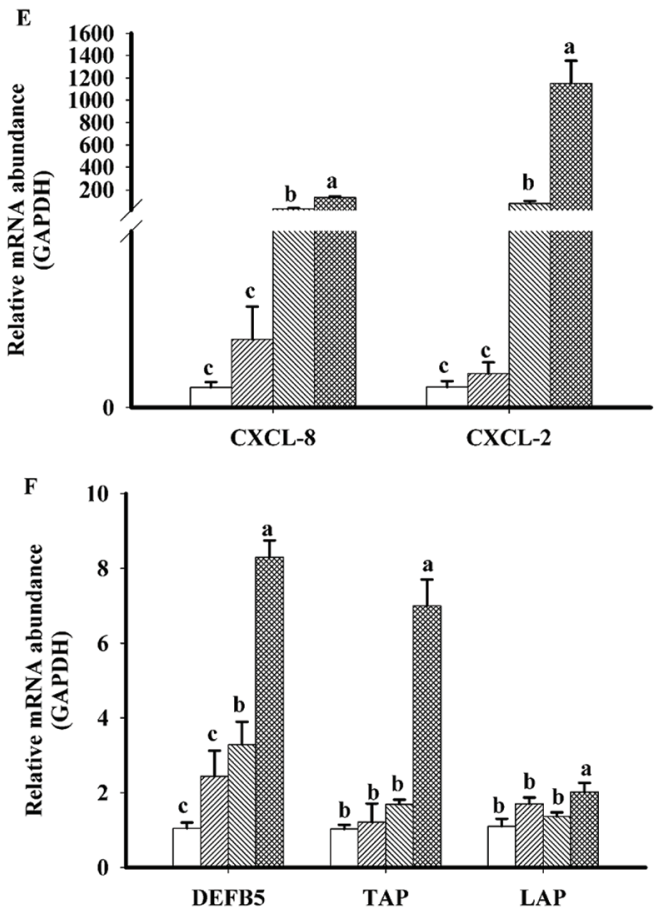

Figure 3. Effects of different treatment schedules of sodium butyrate (NaB) on the mRNA expression of proinflammatory cytokines, chemokines, and defensins during LPS stimulation. (A-C) Cells were treated with $1 \mathrm{~m} M \mathrm{NaB} 18 \mathrm{~h}$ before LPS stimulation. (D-F) Cells were treated with $1 \mathrm{~m} M \mathrm{NaB}$ simultaneous with LPS stimulation $(1 \mu \mathrm{g} / \mathrm{mL}$ for $6 \mathrm{~h})$. Control = cells were treated with $1 \times \mathrm{PBS}$; NaB $=$ cells were pretreated with $1 \mathrm{mM} \mathrm{NaB}$ for $18 \mathrm{~h}$ and then treated with $1 \times \mathrm{PBS}$ for another $6 \mathrm{~h}$; LPS = cells were pretreated with $1 \times$ PBS for $18 \mathrm{~h}$ and then treated with $1 \mu \mathrm{g} / \mathrm{mL}$ of LPS for $6 \mathrm{~h}$; NaB + LPS = cells were pretreated with $1 \mathrm{mM}$ of NaB for $18 \mathrm{~h}$, followed by $1 \mu \mathrm{g} / \mathrm{mL}$ of LPS stimulation for another $6 \mathrm{~h} ; \mathrm{n}=3$. All data presented as mean \pm SEM. Different lowercase letters on the tops of bars of different groups indicate significant differences $(P<0.05)$; groups with the same letters indicate insignificant differences $(P>0.05)$.

\section{Relationship Between Histone Acetylation} and Upregulation of Proinflammatory Cytokines, Chemokines, and $\beta$-Defensin by $\mathrm{NaB}$ During LPS Stimulation

As a histone deacetylase inhibitor (Davie, 2003), $\mathrm{NaB}$ has been widely studied in the modulation of the immune response (Place et al., 2005; Zeng et al., 2013). Inhibition of histone deacetylase will subsequently increase histone acetylation, leading to a more open structure of chromatin, and this change will promote gene transcription (Ellenbroek and Youn, 2016). Thus, the greater protein abundance of acetylated histone $\mathrm{H} 3$ in cultures with $\mathrm{NaB}+$ LPS than in the control $(P$ 
$<0.05$, Figure 7A, C) in the present study indicated that the promoting effect of $\mathrm{NaB}$ on proinflammatory cytokines, chemokines, and $\beta$-defensin expression might act as a histone deacetylase inhibitor. Although genespecific promoter analysis was not conducted in the present study, previous data have demonstrated that accessibility of the TNF promoter is increased in response to $\mathrm{NaB}$ in macrophages during PMA stimulation (Lee et al., 2003). Therefore, epigenetic mechanisms might also be involved in the promoting effect of $\mathrm{NaB}$
A

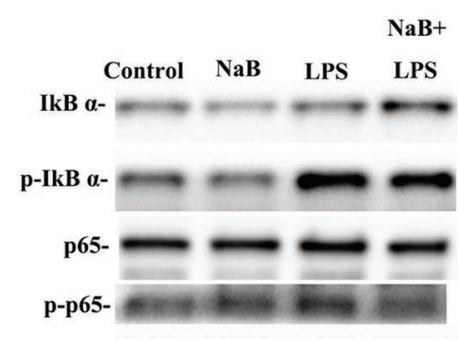

beta-actin-
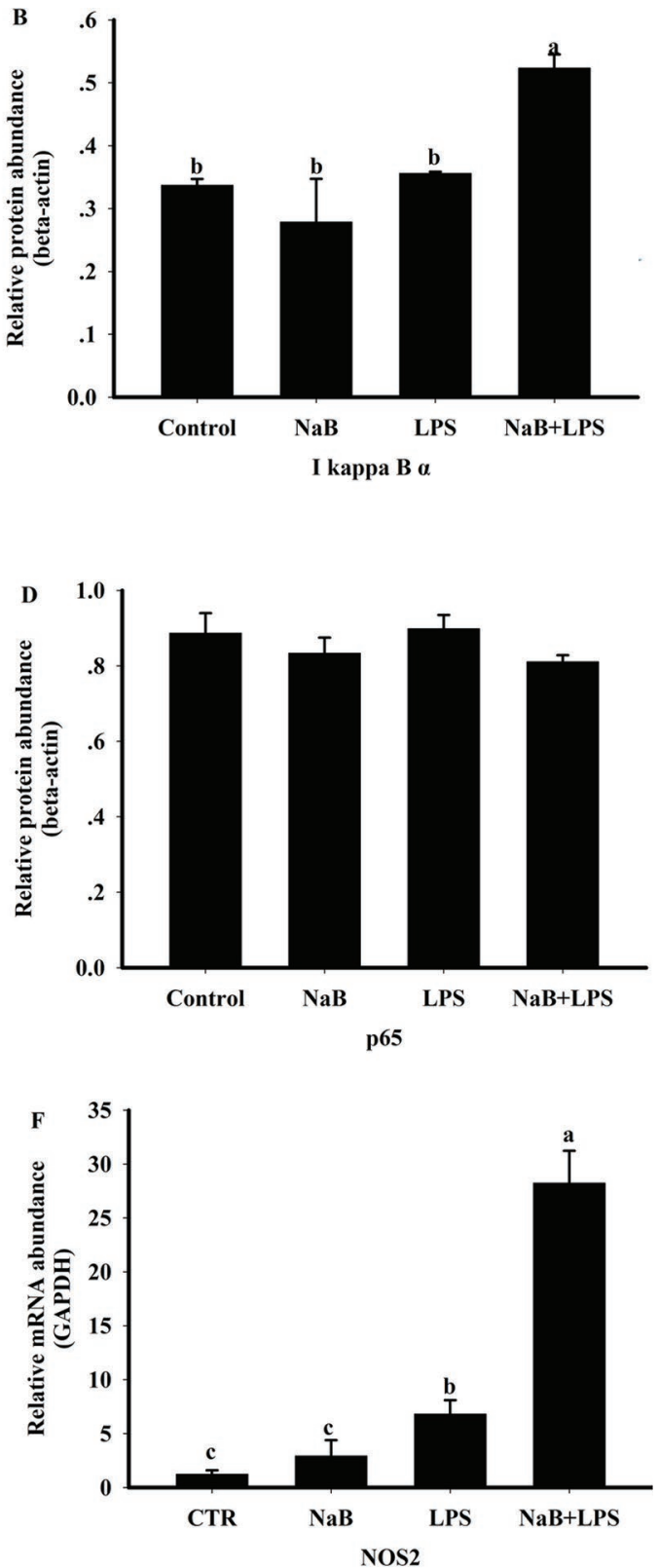

Figure 4. Effects of sodium butyrate (NaB) on NF- $\kappa B$ signaling during LPS stimulation. (A) Bands of the proteins related to NF- $\kappa B$ signaling. (B-E) Quantification of the bands in Western blots. (F) Relative mRNA expression of inducible nitric oxide synthase (NOS2) in response to $\mathrm{NaB}+$ LPS treatment. Control $=$ cells were treated with $1 \times \mathrm{PBS} ; \mathrm{NaB}=$ cells were pretreated with $1 \mathrm{~m} M \mathrm{NaB}$ for $18 \mathrm{~h}$ and then treated with $1 \times$ PBS for another $6 \mathrm{~h}$; LPS $=$ cells were pretreated with $1 \times$ PBS for $18 \mathrm{~h}$ and then treated with $1 \mu \mathrm{g} / \mathrm{mL}$ of LPS for $6 \mathrm{~h} ; \mathrm{NaB}+\mathrm{LPS}=$ cells were pretreated with $1 \mathrm{mM} \mathrm{NaB}$ for $18 \mathrm{~h}$ followed by stimulation with $1 \mu \mathrm{g} / \mathrm{mL}$ of LPS for another $6 \mathrm{~h} ; \mathrm{n}=3$. p- $=$ phosphorylated. All data presented as mean \pm SEM. Different lowercase letters on the tops of bars of different groups indicate significant differences $(P<0.05)$; groups with the same letters indicate insignificant differences $(P>0.05)$. 
on the expression of genes related to the innate immune response, but additional studies are needed to elucidate the underlying mechanism.
Higher levels of transcription of TNF, IL1B, CXCL8, DEFB5, and TAP were observed in cultures with $\mathrm{NaB}$ + LPS $(P<0.05$, Figure 7D-H) than in cultures treated

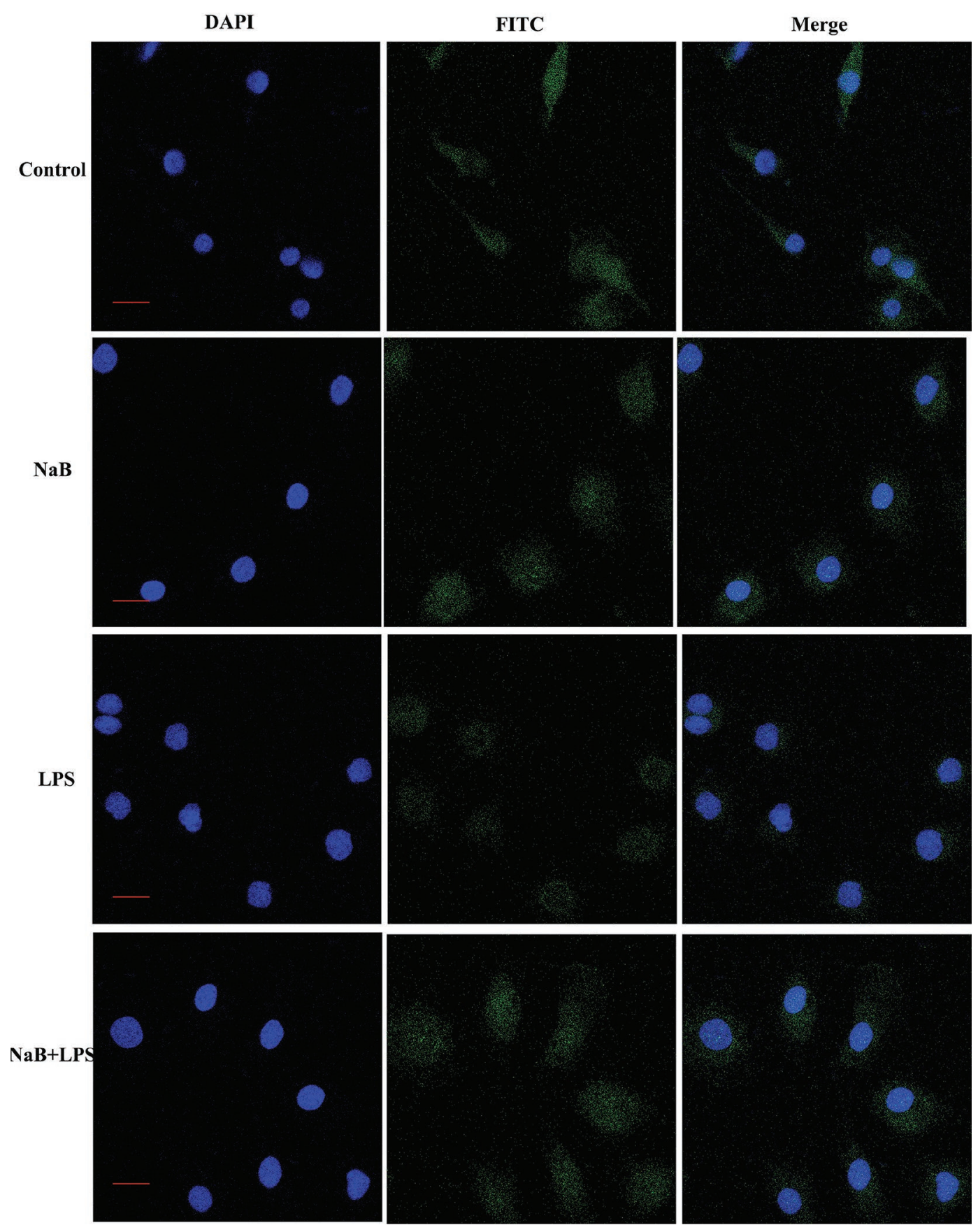

Figure 5. Effects of sodium butyrate $(\mathrm{NaB})$ on the translocation of NF- $\kappa \mathrm{B}$ from cytoplasm to nucleus during LPS stimulation. Control = cells were treated with $1 \times \mathrm{PBS} ; \mathrm{NaB}=$ cells were pretreated with $1 \mathrm{~m} M \mathrm{NaB}$ for $18 \mathrm{~h}$ and then treated with $1 \times$ PBS for another 6 h; LPS $=$ cells were pretreated with $1 \times$ PBS for $18 \mathrm{~h}$ and then treated with $1 \mu \mathrm{g} / \mathrm{mL}$ of LPS for $6 \mathrm{~h}$; NaB + LPS $=$ cells were pretreated with $1 \mathrm{~m} M$ NaB for $18 \mathrm{~h}$ followed by stimulation with $1 \mu \mathrm{g} / \mathrm{mL}$ of LPS for another $6 \mathrm{~h}$. Antibody of NF- $\kappa \mathrm{B}$ subunit p65 and FITC-conjugated secondary antibody

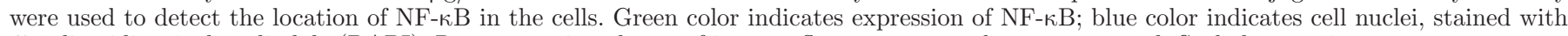
4',6-diamidino-2-phenylindole (DAPI). Representative photos of immunofluorescence results are presented. Scale bar $=50 \mu \mathrm{m}$. 

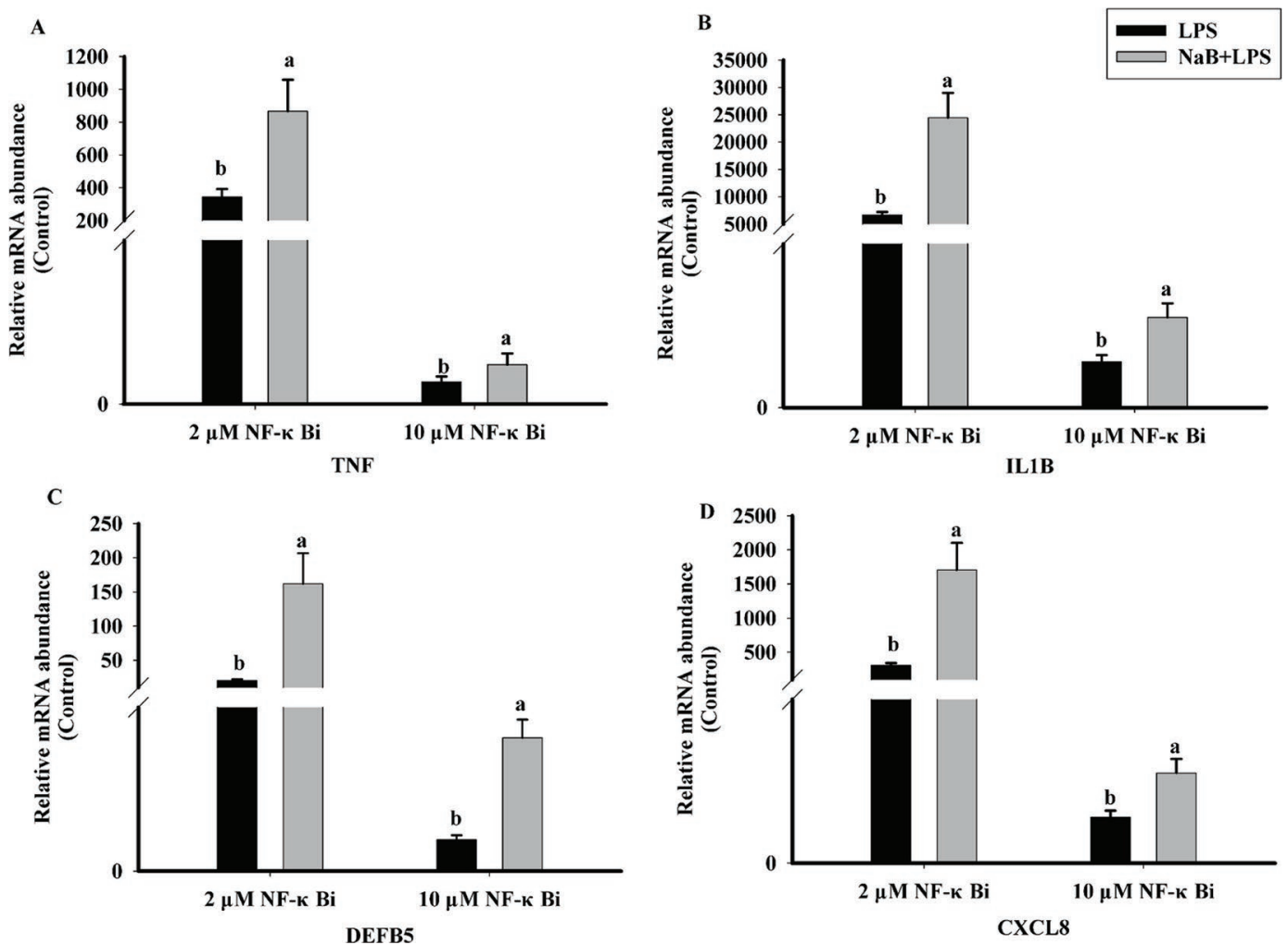

Figure 6. Relationships between NF- $\kappa \mathrm{B}$ signaling and the upregulation of proinflammatory cytokines, chemokines, and $\beta$-defensin transcription by sodium butyrate (NaB) during LPS stimulation. (A-D) Relative mRNA abundance of TNF (A), IL1B (B), DEFB5 (C), and CXCL8 (D). MAC-T cells were pretreated with 2 or $10 \mu M$ NF- $\kappa$ B inhibitor (NF- $\kappa B i, B A Y$ 11-7085) for $1 \mathrm{~h}$ before LPS stimulation, and mRNA expression of $T N F, I L 1 B$, and DEFB5 relative to control are presented. LPS $=$ cells were pretreated with $1 \times P B S$ for $18 \mathrm{~h}$ and then treated with $1 \mu \mathrm{g} / \mathrm{mL}$ of LPS for $6 \mathrm{~h}$; NaB + LPS $=$ cells were pretreated with $1 \mathrm{mM} \mathrm{NaB}$ for $18 \mathrm{~h}$ followed by stimulation with $1 \mu \mathrm{g} / \mathrm{mL}$ of LPS for another $6 \mathrm{~h}$; $\mathrm{n}$ $=3$. All data presented as mean \pm SEM. Different lowercase letters on the tops of bars of different groups indicate significant differences $(P<$ $0.05)$; groups with the same letters indicate insignificant differences $(P>0.05)$.

with TSA + LPS in the present study. Trichostatin A (TSA) is a specific histone deacetylase inhibitor. Thus, these data indicate that other mechanisms in addition to epigenetic ones are involved in the promotion of the transcription of genes related to the innate immune response by $\mathrm{NaB}$ during LPS stimulation.

\section{Role of MAPK Signaling in the Upregulatory Effect of $\mathrm{NaB}$ on the Expression of Proinflammatory Cytokines, Chemokines, and $\beta$-Defensin During LPS Stimulation}

Major components of MAPK signaling pathways, Erk 1 and 2, p38 MAPK, and JNK regulate intracellular processes related to cell proliferation, survival, and immune response (Liu et al., 2007; Kim and Choi, 2010). Studies have shown that Erk 1 and 2, p38 MAPK, and JNK signaling play crucial roles in the transcription of TNF and IL1B (Rutault et al., 2001; Lu et al., 2007; Sato et al., 2012; Arthur and Ley, 2013; Lim et al.,
2014). Additionally, mitogen-activated protein kinase (JNK and p38 MAPK) signaling was found to be involved in the upregulation of $\beta$-defensin 9 expression by NaB in chickens (Sunkara et al., 2014). We observed a greater abundance of phosphorylated p38 MAPK, JNK, and Erk 1 and 2 proteins $(P<0.05$, Figure 8$)$ in cultures with $\mathrm{NaB}+$ LPS than in those with LPS stimulation only. Together with the elevated TNF, $I L 1 B$, and DEFB5 transcription in response to $\mathrm{NaB}+$ LPS treatment in the present study, this suggested that MAPK signaling might be involved in the effect of $\mathrm{NaB}$ on mRNA transcripts from genes involved in the innate immune response during LPS stimulation.

Furthermore, inhibitors of p38 MAPK (SB), JNK (JNi), and Erk 1 and 2 (AG) attenuated the upregulation of $T N F$ transcription by $\mathrm{NaB}(P<0.05$, Figure $9 \mathrm{~A})$ during LPS stimulation. Lower transcription of $I L 1 B$ $(P<0.05$, Figure 9B) was observed only in cultures with $\mathrm{AG}+\mathrm{NaB}+\mathrm{LPS}$, rather than in cultures with $\mathrm{NaB}+$ LPS, which is consistent with a previous finding 

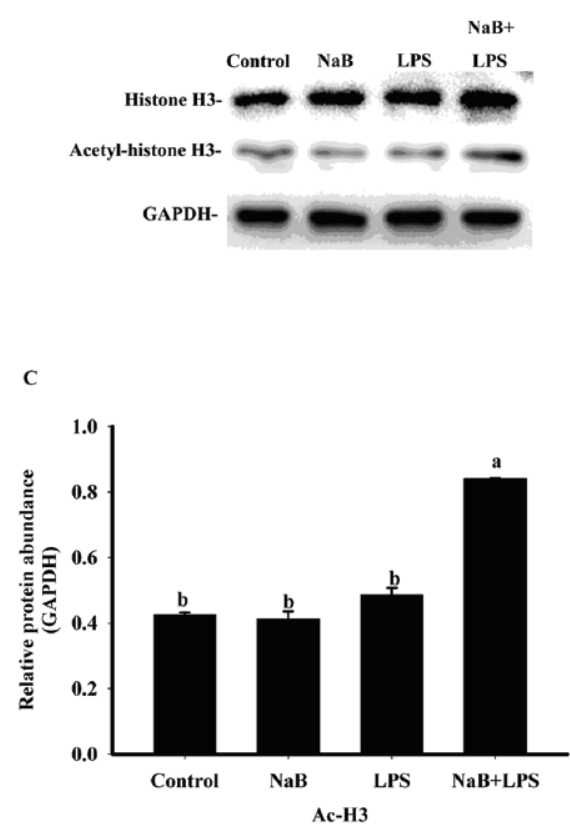

E

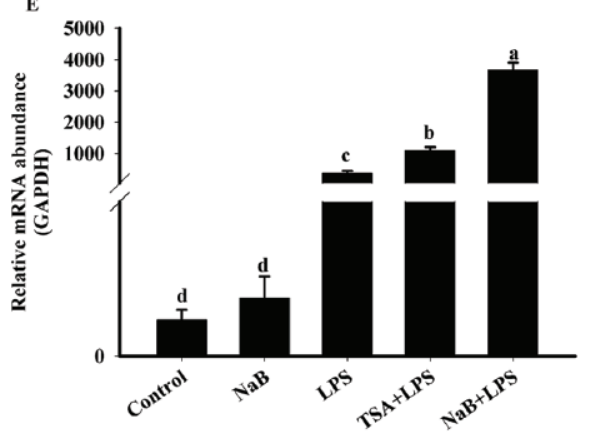

IL1B

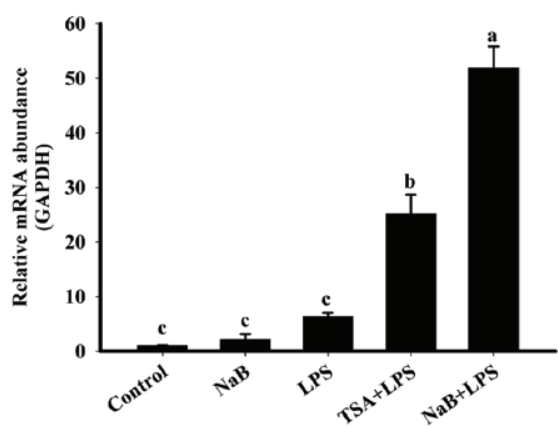

DEFB5
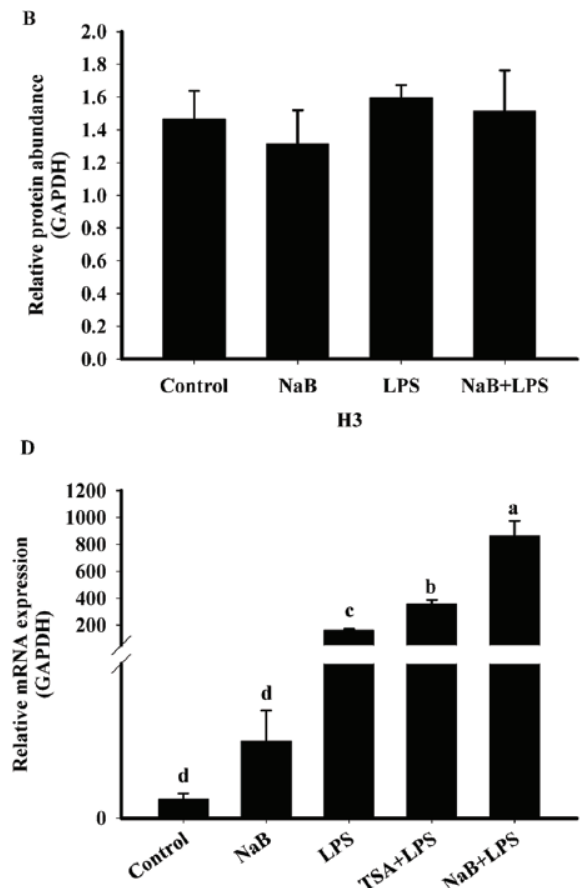

TNF

$\mathbf{F}$

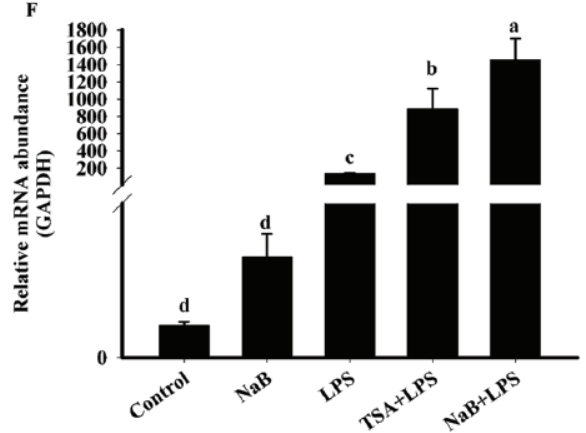

CXCL 8

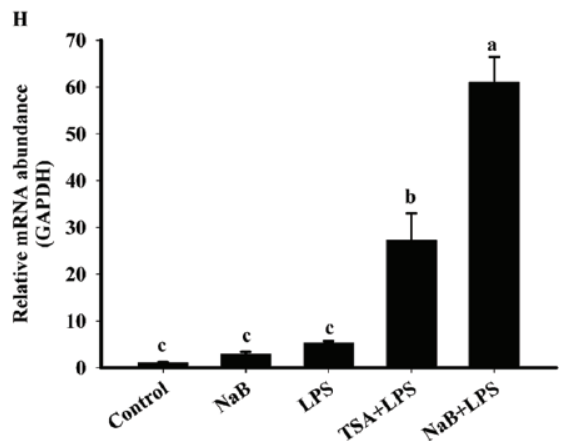

TAP

Figure 7. Relationship between histone acetylation and the upregulation of proinflammatory cytokines, chemokines, and $\beta$-defensin transcription by sodium butyrate $(\mathrm{NaB})$ during LPS stimulation. (A) Bands of the protein related to histone H3 and acetylated histone H3. (B-C) Quantification of the bands from Western blots. (D-H) Relative mRNA abundance of TNF, IL1B, CXCL8, DEFB5, and TAP. Control = cells were treated with $1 \times \mathrm{PBS} ; \mathrm{NaB}=$ cells were pretreated with $1 \mathrm{~m} M \mathrm{NaB}$ for $18 \mathrm{~h}$ and then treated with $1 \times$ PBS for another 6 h; LPS $=$ cells were pretreated with $1 \times$ PBS for $18 \mathrm{~h}$ and then treated with $1 \mu \mathrm{g} / \mathrm{mL}$ of LPS for $6 \mathrm{~h}$ : TSA + LPS = cells were pretreated with $1 \mathrm{~m} M$ NaB for $18 \mathrm{~h}$ followed by stimulation with $1 \mu \mathrm{g} / \mathrm{mL}$ of LPS for another $6 \mathrm{~h}, 100 \mu M$ trichostatin A (TSA) applied for 30 min before 6 h of LPS stimulation; $\mathrm{NaB}+\mathrm{LPS}=$ cells were pretreated with $1 \mathrm{~m} M \mathrm{NaB}$ for $18 \mathrm{~h}$ followed by stimulation with $1 \mu \mathrm{g} / \mathrm{mL}$ of LPS for another $6 \mathrm{~h} ; \mathrm{n}=3$. All data presented as mean \pm SEM. Different lowercase letters on the tops of bars of different groups indicate significant differences $(P<0.05)$; groups with the same letters indicate insignificant differences $(P>0.05)$. 
$\mathbf{A}$

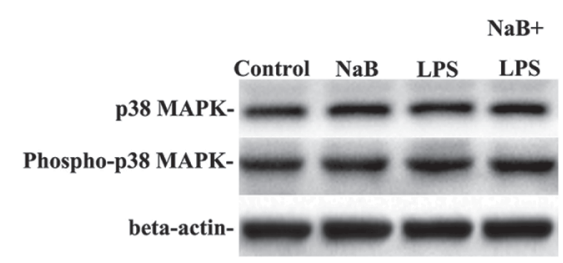

C
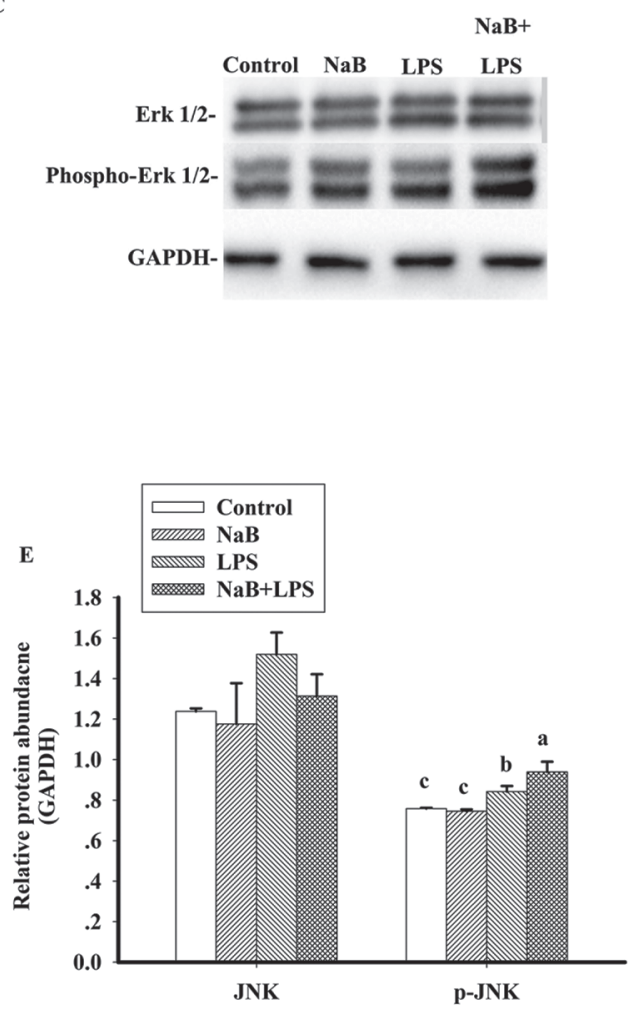

B
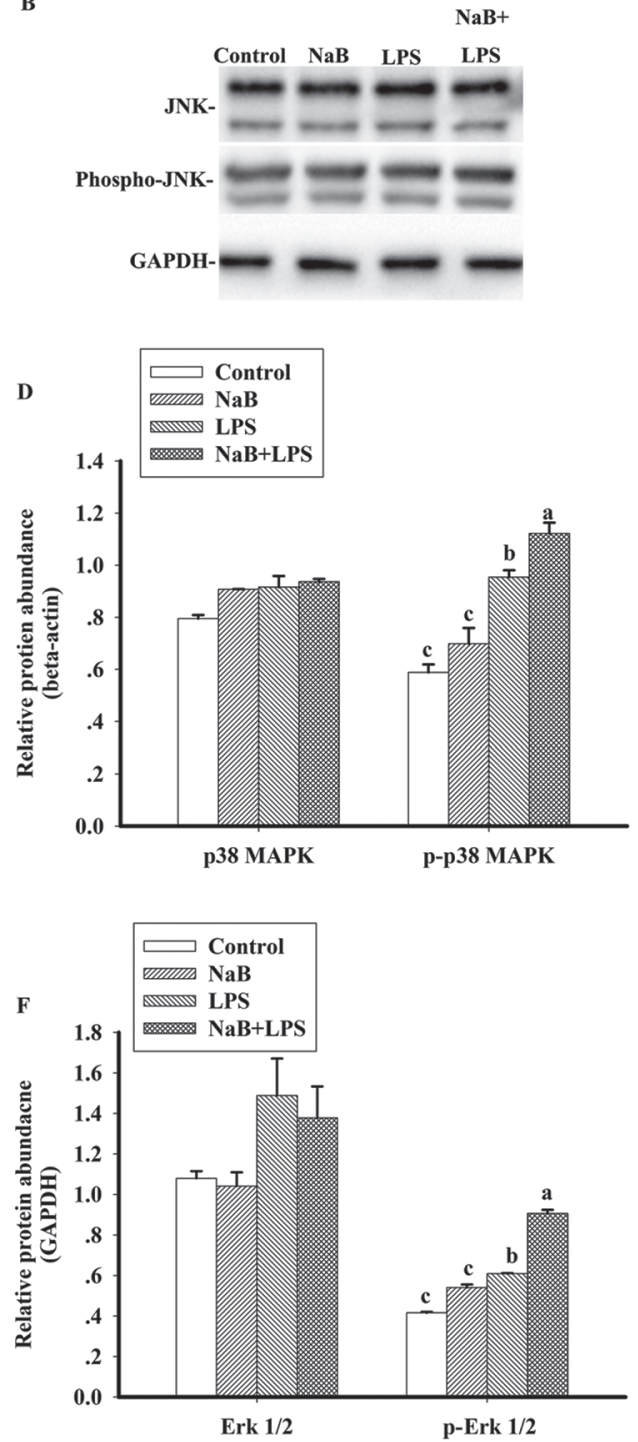

Figure 8. Effect of sodium butyrate (NaB) on activation of mitogen-activated protein kinase (MAPK) signaling during LPS stimulation. $(\mathrm{A}-\mathrm{C})$ Bands of the protein related to MAPK signaling. (D-F) Quantification of the bands of Western blots analysis. Control = cells were treated with $1 \times \mathrm{PBS} ; \mathrm{NaB}=$ cells were pretreated with $1 \mathrm{mM} \mathrm{NaB}$ for $18 \mathrm{~h}$ and then treated with $1 \times$ PBS for another 6 h; LPS $=$ cells were pretreated with $1 \times$ PBS for $18 \mathrm{~h}$ and then treated with $1 \mu \mathrm{g} / \mathrm{mL}$ of LPS for $6 \mathrm{~h}$; NaB + LPS $=$ cells were pretreated with $1 \mathrm{~m} M$ NaB for $18 \mathrm{~h}$ followed by stimulation with $1 \mu \mathrm{g} / \mathrm{mL}$ of LPS for another $6 \mathrm{~h} ; \mathrm{n}=3$. Phospho- and $\mathrm{p}-=$ phosphorylated. All data presented as mean \pm SEM. Different lowercase letters on the tops of bars of different groups indicate significant differences $(P<0.05)$; groups with the same letters indicate insignificant differences $(P>0.05)$.

that the expression of IL1B is Erk signaling-dependent in monocytes and macrophages (Ghonime et al., 2014). A previous study suggested that p38 MAPK was the main component of MAPK signaling that regulated the expression of sheep $\beta$-defensin 5 initiated by LPS (Li et al., 2016). The mRNA abundance of DEFB5 $(P<0.05$, Figure 9C) was attenuated in cultures treated with p38 MAPK, JNK, and Erk inhibitors during LPS stimulation, compared with cultures with $\mathrm{NaB}+$ LPS in the present study, and this result indicated that p38 MAPK,
JNK, and Erk all play crucial roles in the promoting effect of $\mathrm{NaB}$ on the transcription of DEFB5 during LPS stimulation. Increased transcription of $C X C L 8$ $(P<0.05$, Figure 9D) in cultures treated with $\mathrm{NaB}$ + LPS compared with cultures treated with LPS only was attenuated by p38 and Erk inhibitors rather than JNK inhibitor in the present study. This observation agrees with a previous study that identified a crucial role of Erks and p38 MAPK in LPS-induced CXCL8 transcription in hDPSCs (He et al., 2013). Thus, the 
A

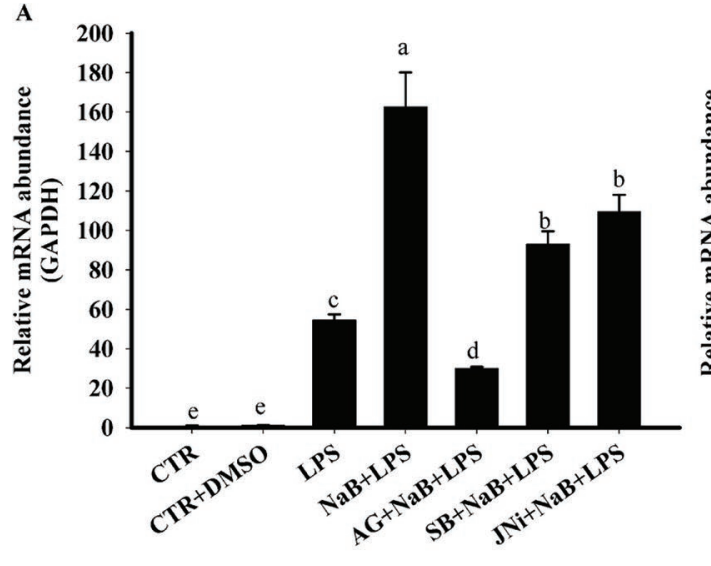

TNF

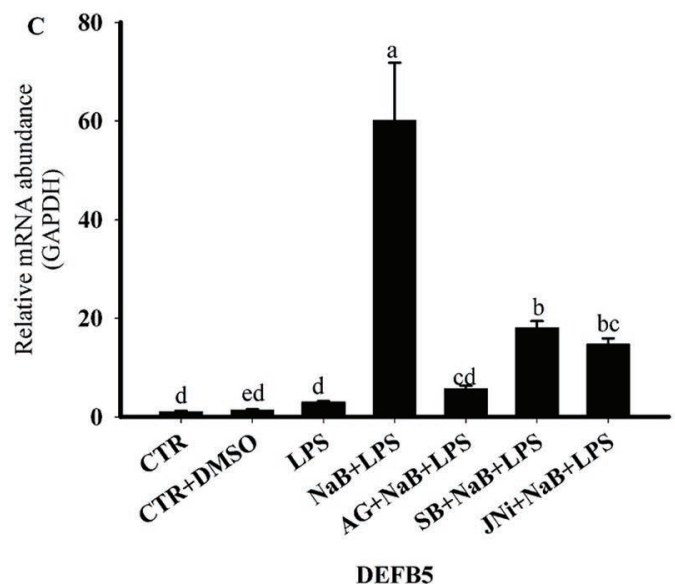

B

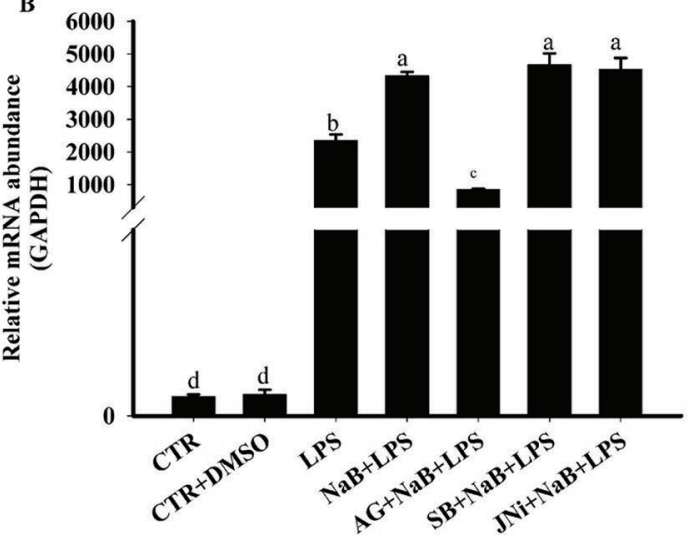

IL1B

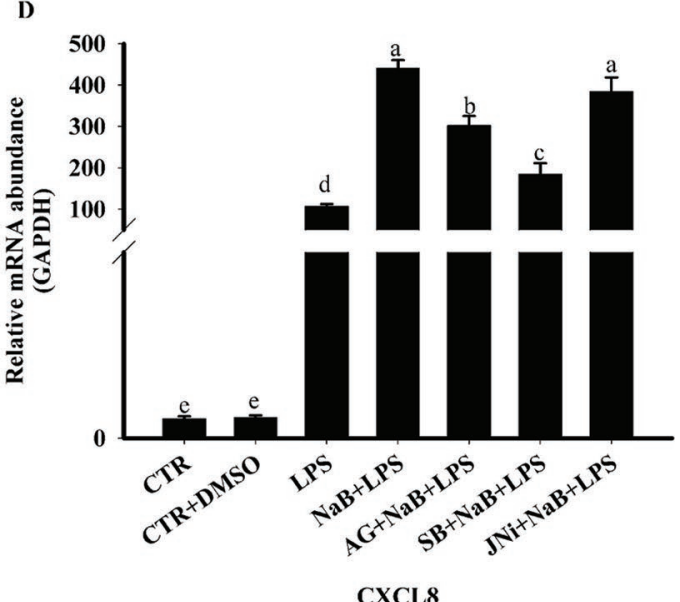

Figure 9. Relationship between mitogen-activated protein kinase (MAPK) signaling and the upregulation of proinflammatory cytokines, chemokines, and $\beta$-defensin transcription by sodium butyrate (NaB) during LPS stimulation. (A-D) Relative mRNA abundance of TNFA (A), $I L 1 B(\mathrm{~B})$, DEFB5 (C), and CXCL8 (D). CTR = control, cells were treated with $1 \times$ PBS; CTR + DMSO = cells were treated with $1 \times$ PBS and dimethyl sulfoxide (DMSO); $\mathrm{NaB}=$ cells were pretreated with $1 \mathrm{~m} M$ of $\mathrm{NaB}$ for $18 \mathrm{~h}$ and then treated with $1 \times$ PBS for another 6 h; LPS $=$ cells were pretreated with $1 \times$ PBS for $18 \mathrm{~h}$ and then treated with $1 \mu \mathrm{g} / \mathrm{mL}$ of LPS for $6 \mathrm{~h} ; \mathrm{NaB}+$ LPS $=$ cells were pretreated with 1 m $M$ of $\mathrm{NaB}$ for $18 \mathrm{~h}$ followed by stimulation with $1 \mu \mathrm{g} / \mathrm{mL}$ of LPS for another $6 \mathrm{~h}$; AG $+\mathrm{NaB}+\mathrm{LPS}=$ cells were pretreated with $1 \mathrm{~m} M$ NaB for $18 \mathrm{~h}$ and then treated with $30 \mu M$ AG126 (AG) and LPS $(1 \mu \mathrm{g} / \mathrm{mL})$ for $6 \mathrm{~h}$; SB $+\mathrm{NaB}+\mathrm{LPS}=$ cells were pretreated with $1 \mathrm{~m} M$ NaB for 18 $\mathrm{h}$ followed by LPS $(1 \mu \mathrm{g} / \mathrm{mL})$ for $6 \mathrm{~h}$, and $10 \mu M$ SB203580 was used at $\mathrm{h} 16$ of incubation and the medium was removed at $\mathrm{h} 18$ of incubation; $\mathrm{JNi}+\mathrm{NaB}+\mathrm{LPS}=$ cells were pretreated with $1 \mathrm{mM} \mathrm{NaB}$ for $18 \mathrm{~h}$ followed by LPS $(1 \mu \mathrm{g} / \mathrm{mL})$ for $6 \mathrm{~h}$, and $3 \mu M$ JNK-IN-8 was used $30 \mathrm{~min}$ before the end of 18 -h incubation and the medium was removed at $\mathrm{h} 18$ of incubation; $\mathrm{n}=3$. All data presented as mean \pm SEM. Different lowercase letters on the tops of bars of different groups indicate significant differences $(P<0.05)$; groups with the same letters indicate insignificant differences $(P>0.05)$.

results of the present study suggest that MAPK signaling plays a crucial role in the boosting effect of $\mathrm{NaB}$ on the expression of secreted factors (proinflammatory cytokines, chemokines, and $\beta$-defensins) related to the innate immune response initiated by LPS.

\section{NaB Increases mRNA Abundance of Proinflammatory Cytokines, Chemokines, and $\beta$-Defensin During E. coli Stimulation}

Escherichia coli is one of the major causative pathogens of mastitis (Thompson-Crispi et al., 2014). We isolated E. coli from a case of clinical mastitis. This sample of $E$. coli was identified, and it belongs to the serotype O15 strain. We used it to test the effects of $\mathrm{NaB}$ on the innate immune response initiated by $E$. coli in MAC-T cells. Upregulation of TNF, IL1B, CXCL2, $C X C L 8, D E F B 5$, and TAP transcription in cultures with $\mathrm{NaB}+E$. coli than in cultures treated with heatinactivated $E$. coli only $(P<0.05$, Figure 10$)$ in the present study confirmed the innate immune responseboosting property of $\mathrm{NaB}$ during infection. This finding suggests that $\mathrm{NaB}$ has potential for prevention or treatment of mastitis in dairy cattle, which may reduce the 

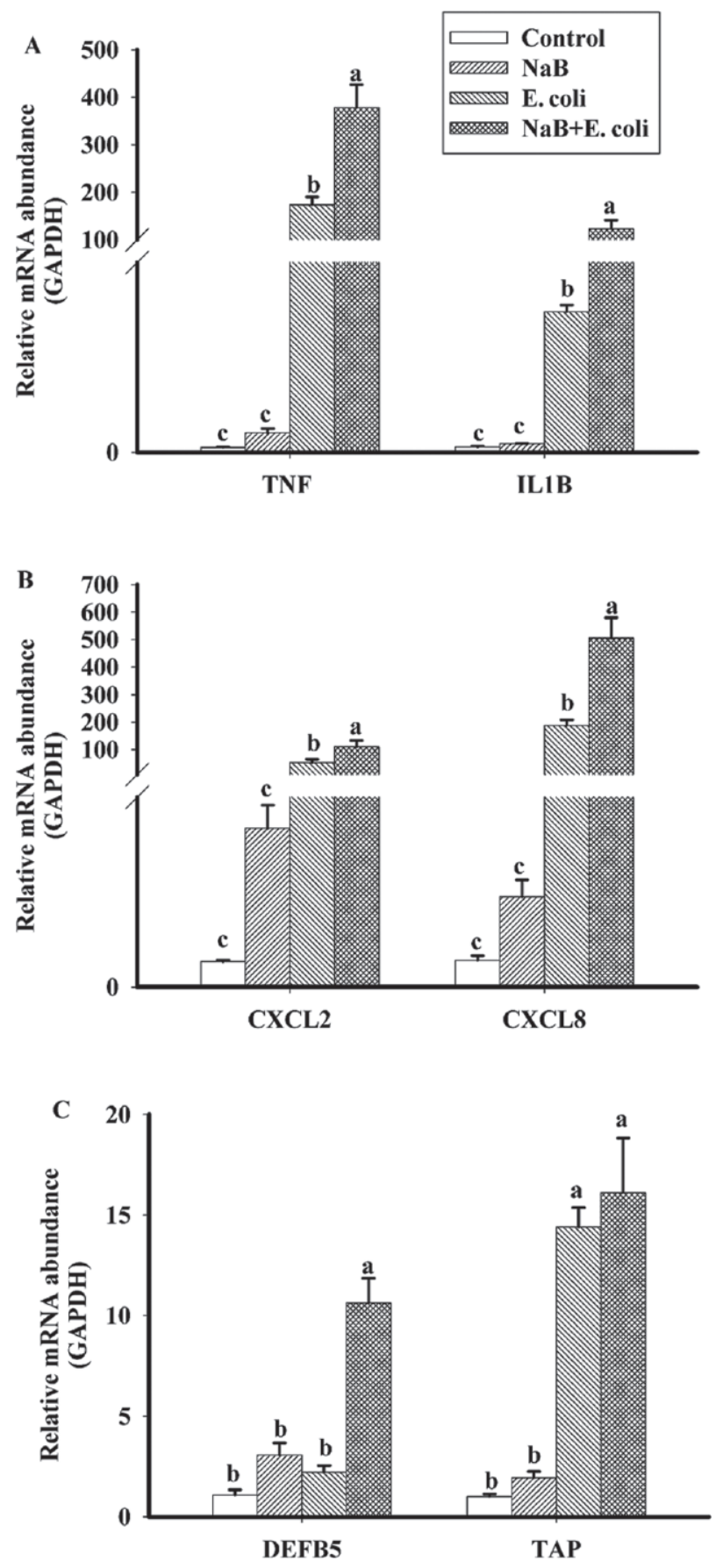

Figure 10. Effects of sodium butyrate $(\mathrm{NaB})$ on mRNA abundance of proinflammatory cytokines (TNF, IL1B), chemokines (CXCL2, $C X C L 8)$, and $\beta$-defensins (DEFB5, TAP) in response to heat-deactivated Escherichia coli. (A-C) Relative mRNA abundance of proinflammatory cytokines (A), chemokines (B), and $\beta$-defensins (C). Control $=$ cells were treated with $1 \times \mathrm{PBS} ; \mathrm{NaB}=$ cells were pretreated with $1 \mathrm{mM} \mathrm{NaB}$ for $18 \mathrm{~h}$ and then treated with $1 \times$ PBS for another $6 \mathrm{~h}$; E. coli $=$ cells were pretreated with $1 \times$ PBS for $18 \mathrm{~h}$ and then treated with E. coli $\left(1 \times 10^{5} \mathrm{cfu} / \mathrm{mL}\right)$ for $6 \mathrm{~h} ; \mathrm{NaB}+E$. coli $=$ cells were pretreated with $1 \mathrm{~m} M \mathrm{NaB}$ for $18 \mathrm{~h}$ followed by $E$. coli $\left(1 \times 10^{5} \mathrm{cfu} /\right.$ $\mathrm{mL}$ ) stimulation for another $6 \mathrm{~h} ; \mathrm{n}=3$. All data presented as mean \pm SEM. Different lowercase letters on the tops of bars of different groups indicate significant differences $(P<0.05)$; groups with the same letters indicate insignificant differences $(P>0.05)$. use of antibiotics and improve recovery of the infected mammary gland.

\section{CONCLUSIONS}

The innate immune response is a crucial line of defense against infection. Sodium butyrate enhanced the innate immune response initiated by LPS via enhancing the expression of proinflammatory cytokines, chemokines, and $\beta$-defensins in bovine mammary epithelial cells. Furthermore, acetylation of histone H3 and activation of $\mathrm{p} 38, \mathrm{JNK}$, and Erk signaling but not NF- $\kappa \mathrm{B}$ signaling played a key role in the enhancement of the LPS-induced innate immune response by $\mathrm{NaB}$.

\section{ACKNOWLEDGMENTS}

This study was supported by the National Natural Science Foundation of China (Beijing; 31872528; 31672618; 31702301), the Fundamental Research Funds for the Central Universities (Beijing, China; JCQY201905) and the Priority Academic Program Development of Jiangsu Higher Education Institutions (PAPD; Nanjing, China). The authors confirmed that there were no conflicts of interest.

\section{REFERENCES}

Alexander, C., and E. T. Rietschel. 2001. Bacterial lipopolysaccharides and innate immunity. J. Endotoxin Res. 7:167-202.

Alva-Murillo, N.. I. Medina-Estrada, M. Baez-Magana, A. Ochoa-Zarzosa, and J. E. Lopez-Meza. 2015. The activation of the TLR2/p38 pathway by sodium butyrate in bovine mammary epithelial cells is involved in the reduction of Staphylococcus aureus internalization. Mol. Immunol. 68(2 Pt B):445-455. https://doi.org/10.1016/ j.molimm.2015.09.025.

Arthur, J. S., and S. C. Ley. 2013. Mitogen-activated protein kinases in innate immunity. Nat. Rev. Immunol. 13:679-692. https://do .org/10.1038/nri3495.

Borthwick, L. A. 2016. The IL-1 cytokine family and its role in inflammation and fibrosis in the lung. Semin. Immunopathol. 38:517534. https://doi.org/10.1007/s00281-016-0559-z.

Davie, J. R. 2003. Inhibition of histone deacetylase activity by butyrate. J. Nutr. 133(Suppl.):2485S-2493S. https://doi.org/10.1093/ jn/133.7.2485S.

Ellenbroek, B., and J. Youn. 2016. Chapter 6: Drug addiction. Pages 143-172 in Gene-Environment Interactions in Psychiatry. B. Ellenbroek and J. Youn, ed. Academic Press, San Diego, CA.

Ghonime, M. G., O. R. Shamaa, S. Das, R. A. Eldomany, T. Fernandes-Alnemri, E. S. Alnemri, M. A. Gavrilin, and M. D. Wewers. 2014. Inflammasome priming by lipopolysaccharide is dependent upon ERK signaling and proteasome function. J. Immunol. 192:3881-3888. https://doi.org/10.4049/jimmunol.1301974.

Goldammer, T., H. Zerbe, A. Molenaar, H. J. Schuberth, R. M. Brunner, S. R. Kata, and H. M. Seyfert. 2004. Mastitis increases mammary mRNA abundance of $\beta$-defensin 5 , toll-like-receptor 2 (TLR2), and TLR4 but not TLR9 in cattle. Clin. Diagn. Lab. Immunol. 11:174-185. https://doi.org/10.1128/CDLI.11.1.174-185 2004 .

He, W., T. Qu, Q. Yu, Z. Wang, H. Lv, J. Zhang, X. Zhao, and P. Wang. 2013. LPS induces IL-8 expression through TLR4, MyD88, $\mathrm{NF}-\kappa \mathrm{B}$ and MAPK pathways in human dental pulp stem cells. Int. 
Endod. J. 46:128-136. https://doi.org/10.1111/j.1365-2591.2012 .02096.x.

Kelleher, Z. T., E. N. Potts, M. V. Brahmajothi, M. W. Foster, R. L. Auten, W. M. Foster, and H. E. Marshall. 2011. NOS2 regulation of LPS-induced airway inflammation via S-nitrosylation of $\mathrm{NF} \kappa \mathrm{B}$ p65. Am. J. Physiol. Lung Cell. Mol. Physiol. 301:L327-L333. https://doi.org/10.1152/ajplung.00463.2010.

Kida, Y., T. Shimizu, and K. Kuwano. 2006. Sodium butyrate upregulates cathelicidin gene expression via activator protein-1 and histone acetylation at the promoter region in a human lung epithelial cell line, EBC-1. Mol. Immunol. 43:1972-1981. https://doi .org/10.1016/j.molimm.2005.11.014.

Kim, E. K., and E. J. Choi. 2010. Pathological roles of MAPK signaling pathways in human diseases. Biochim. Biophys. Acta 1802:396-405.

Kulms, D., and T. Schwarz. 2006. NF-кB and cytokines. Pages 283300 in Vitamins and Hormones, Vol. 74. G. Litwack, ed. Academic Press, Cambridge, MA.

Kunkel, S. L., T. Standiford, K. Kasahara, and R. M. Strieter. 1991. Interleukin-8 (IL-8): The major neutrophil chemotactic factor in the lung. Exp. Lung Res. 17:17-23. https://doi.org/10.3109/ 01902149109063278.

Lee, J. Y., N. A. Kim, A. Sanford, and K. E. Sullivan. 2003. Histone acetylation and chromatin conformation are regulated separately at the TNF- $\alpha$ promoter in monocytes and macrophages. J. Leukoc. Biol. 73:862-871. https://doi.org/10.1189/jlb.1202618.

Li, Q., F. Bao, D. Zhi, M. Liu, Q. Yan, X. Zheng, L. Ren, S. Cong, Y. $\mathrm{Li}$, and G. Cao. 2016. Lipopolysaccharide induces SBD-1 expression via the P38 MAPK signaling pathway in ovine oviduct epithelial cells. Lipids Health Dis. 15:127. https://doi.org/10.1186/ s12944-016-0294-4.

Lim, M. X., C. W. Png, C. Y. B. Tay, J. D. W. Teo, H. Jiao, N. Lehming, K. S. W. Tan, and Y. Zhang. 2014. Differential regulation of proinflammatory cytokine expression by mitogen-activated protein kinases in macrophages in response to intestinal parasite infection. Infect. Immun. 82:4789-4801. https://doi.org/10.1128/ IAI.02279-14.

Liu, J., G. Chang, J. Huang, Y. Wang, N. Ma, A. C. Roy, and X. Shen. 2019. Sodium butyrate inhibits the inflammation of lipopolysaccharide-induced acute lung injury in mice by regulating the tolllike receptor 4/nuclear factor $\mathrm{\kappa B}$ signaling pathway. J. Agric. Food Chem. 67:1674-1682. https://doi.org/10.1021/acs.jafc.8b06359.

Liu, Y., E. G. Shepherd, and L. D. Nelin. 2007. MAPK phosphatasesRegulating the immune response. Nat. Rev. Immunol. 7:202-212. https://doi.org/10.1038/nri2035.

Livak, K. J., and T. D. Schmittgen. 2001. Analysis of relative gene expression data using real-time quantitative PCR and the $2^{-\Delta \Delta \mathrm{Ct}}$ method. Methods 25:402-408. https://doi.org/10.1006/meth.2001 .1262 .

Lu, K., C. L. Cho, C. L. Liang, S. D. Chen, P. C. Liliang, S. Y. Wang, and H. J. Chen. 2007. Inhibition of the MEK/ERK pathway reduces microglial activation and interleukin-1- $\beta$ expression in spinal cord ischemia/reperfusion injury in rats. J. Thorac. Cardiovasc. Surg. 133:934-941. https://doi.org/10.1016/j.jtcvs.2006.11.038.

Lu, Y. C., W. C. Yeh, and P. S. Ohashi. 2008. LPS/TLR4 signal transduction pathway. Cytokine 42:145-151. https://doi.org/10.1016/j .cyto.2008.01.006.

Ma, N., G. Chang, J. Huang, Y. Wang, Q. Gao, X. Cheng, J. Liu, and X. Shen. 2019. Cis-9, trans-11-conjugated linoleic acid exerts an anti-inflammatory effect in bovine mammary epithelial cells after Escherichia coli stimulation through NF- $\mathrm{B}$ signaling pathway. J. Agric. Food Chem. 67:193-200. https://doi.org/10.1021/acs.jafc $.8 \mathrm{~b} 05500$.

Machado, R. A., L. de Souza Constantino, C. D. Tomasi, H. A. Rojas, F. S. Vuolo, M. F. Vitto, P. A. Cesconetto, C. T. de Souza, C. Ritter, and F. Dal-Pizzol. 2012. Sodium butyrate decreases the activation of NF- $\mathrm{KB}$ reducing inflammation and oxidative damage in the kidney of rats subjected to contrast-induced nephropathy. Nephrol. Dial. Transplant. 27:3136-3140. https://doi.org/10 .1093/ndt/gfr807.
Meijer, K., P. de Vos, and M. G. Priebe. 2010. Butyrate and other short-chain fatty acids as modulators of immunity: What relevance for health? Curr. Opin. Clin. Nutr. Metab. Care 13:715-721. https: //doi.org/10.1097/MCO.0b013e32833eebe5.

Moyes, K. M., D. E. Graugnard, M. J. Khan, M. Mukesh, and J. J. Loor. 2014. Postpartal immunometabolic gene network expression and function in blood neutrophils are altered in response to prepartal energy intake and postpartal intramammary inflammatory challenge. J. Dairy Sci. 97:2165-2177. https://doi.org/10.3168/jds .2013-7433.

Park, J. S., E. J. Lee, J. C. Lee, W. K. Kim, and H. S. Kim. 2007. Antiinflammatory effects of short chain fatty acids in IFN- $\gamma$-stimulated RAW 264.7 murine macrophage cells: Involvement of NF-kB and ERK signaling pathways. Int. Immunopharmacol. 7:70-77. https:/ /doi.org/10.1016/j.intimp.2006.08.015.

Place, R. F., E. J. Noonan, and C. Giardina. 2005. HDAC inhibition prevents NF- $\kappa \mathrm{B}$ activation by suppressing proteasome activity: Down-regulation of proteasome subunit expression stabilizes IкB $\alpha$. Biochem. Pharmacol. 70:394-406. https://doi.org/10.1016/ j.bcp.2005.04.030.

Rainard, P., and C. Riollet. 2006. Innate immunity of the bovine mammary gland. Vet. Res. 37:369-400. https://doi.org/10.1051/vetres: 2006007.

Roosen, S., K. Exner, S. Paul, J.-M. Schröder, E. Kalm, and C. Looft. 2004. Bovine $\beta$-defensins: Identification and characterization of novel bovine $\beta$-defensin genes and their expression in mammary gland tissue. Mamm. Genome 15:834-842. https://doi.org/10 $.1007 / \mathrm{s} 00335-004-2387-z$.

Rouault, C., V. Pellegrinelli, R. Schilch, A. Cotillard, C. Poitou, J. Tordjman, H. Sell, K. Clement, and D. Lacasa. 2013. Roles of chemokine ligand-2 (CXCL2) and neutrophils in influencing endothelial cell function and inflammation of human adipose tissue. Endocrinology 154:1069-1079. https://doi.org/10.1210/en.2012-1415.

Rutault, K., C. A. Hazzalin, and L. C. Mahadevan. 2001. Combinations of ERK and p38 MAPK inhibitors ablate tumor necrosis factor- $\alpha(\mathrm{TNF}-\alpha)$ mRNA induction. Evidence for selective destabilization of TNF- $\alpha$ transcripts. J. Biol. Chem. 276:6666-6674. https://doi.org/10.1074/jbc.M005486200.

Sato, H., T. Tanaka, and N. Tanaka. 2012. The effect of p38 mitogenactivated protein kinase activation on inflammatory liver damage following hemorrhagic shock in rats. PLoS One 7:e30124. https:// doi.org/10.1371/journal.pone.0030124.

Scheller, J., A. Chalaris, D. Schmidt-Arras, and S. Rose-John. 2011. The pro- and anti-inflammatory properties of the cytokine interleukin-6. Biochim. Biophys. Acta 1813:878-888.

Segain, J.-P., D. R. Blétière, A. Bourreille, V. Leray, N. Gervois, C. Rosales, L. Ferrier, C. Bonnet, H. M. Blottière, and J.-P. Galmiche. 2000. Butyrate inhibits inflammatory responses through NF$\kappa \mathrm{B}$ inhibition: Implications for Crohn's disease. Gut 47:397-403. https://doi.org/10.1136/gut.47.3.397.

Sordillo, L. M., and K. L. Streicher. 2002. Mammary gland immunity and mastitis susceptibility. J. Mammary Gland Biol. 7:135-146. https://doi.org/10.1023/A:1020347818725.

Sun, X., S. Luo, C. Jiang, Y. Tang, Z. Cao, H. Jia, Q. Xu, C. Zhao, J. J. Loor, and C. Xu. 2020. Sodium butyrate reduces bovine mammary epithelial cell inflammatory responses induced by exogenous lipopolysaccharide, by inactivating NF- $\mathrm{B}$ signaling. J. Dairy Sci. 103:8388-8397. https://doi.org/10.3168/jds.2020-18189.

Sunkara, L. T., X. Zeng, A. R. Curtis, and G. Zhang. 2014. Cyclic AMP synergizes with butyrate in promoting $\beta$-defensin 9 expression in chickens. Mol. Immunol. 57:171-180. https://doi.org/10 .1016/j.molimm.2013.09.003.

Swanson, K., S. Gorodetsky, L. Good, S. Davis, D. Musgrave, K. Stelwagen, V. Farr, and A. Molenaar. 2004. Expression of a $\beta$-defensin mRNA, lingual antimicrobial peptide, in bovine mammary epithelial tissue is induced by mastitis. Infect. Immun. 72:7311-7314. https://doi.org/10.1128/IAI.72.12.7311-7314.2004.

Thompson-Crispi, K., H. Atalla, F. Miglior, and B. A. Mallard. 2014. Bovine mastitis: Frontiers in immunogenetics. Front. Immunol. 5:493. https://doi.org/10.3389/fimmu.2014.00493. 
Yang, L., R. M. Froio, T. E. Sciuto, A. M. Dvorak, R. Alon, and F. W. Luscinskas. 2005. ICAM-1 regulates neutrophil adhesion and transcellular migration of TNF- $\alpha$-activated vascular endothelium under flow. Blood 106:584-592. https://doi.org/10.1182/blood -2004-12-4942.

Yang, W., A. Molenaar, B. Kurts-Ebert, and H. M. Seyfert. 2006. NF$\kappa \mathrm{B}$ factors are essential, but not the switch, for pathogen-related induction of the bovine $\beta$-defensin 5 -encoding gene in mammary epithelial cells. Mol. Immunol. 43:210-225. https://doi.org/10 .1016/j.molimm.2005.02.003.

Zasloff, M. 2002. Antimicrobial peptides of multicellular organisms. Nature 415:389-395. https://doi.org/10.1038/415389a.
Zeng, X., L. T. Sunkara, W. Jiang, M. Bible, S. Carter, X. Ma, S. Qiao, and G. Zhang. 2013. Induction of porcine host defense peptide gene expression by short-chain fatty acids and their analogs. PLoS One 8:e72922. https://doi.org/10.1371/journal.pone.0072922.

\section{ORCIDS}

Xiangzhen Shen (๑) https://orcid.org/0000-0002-3020-5010 